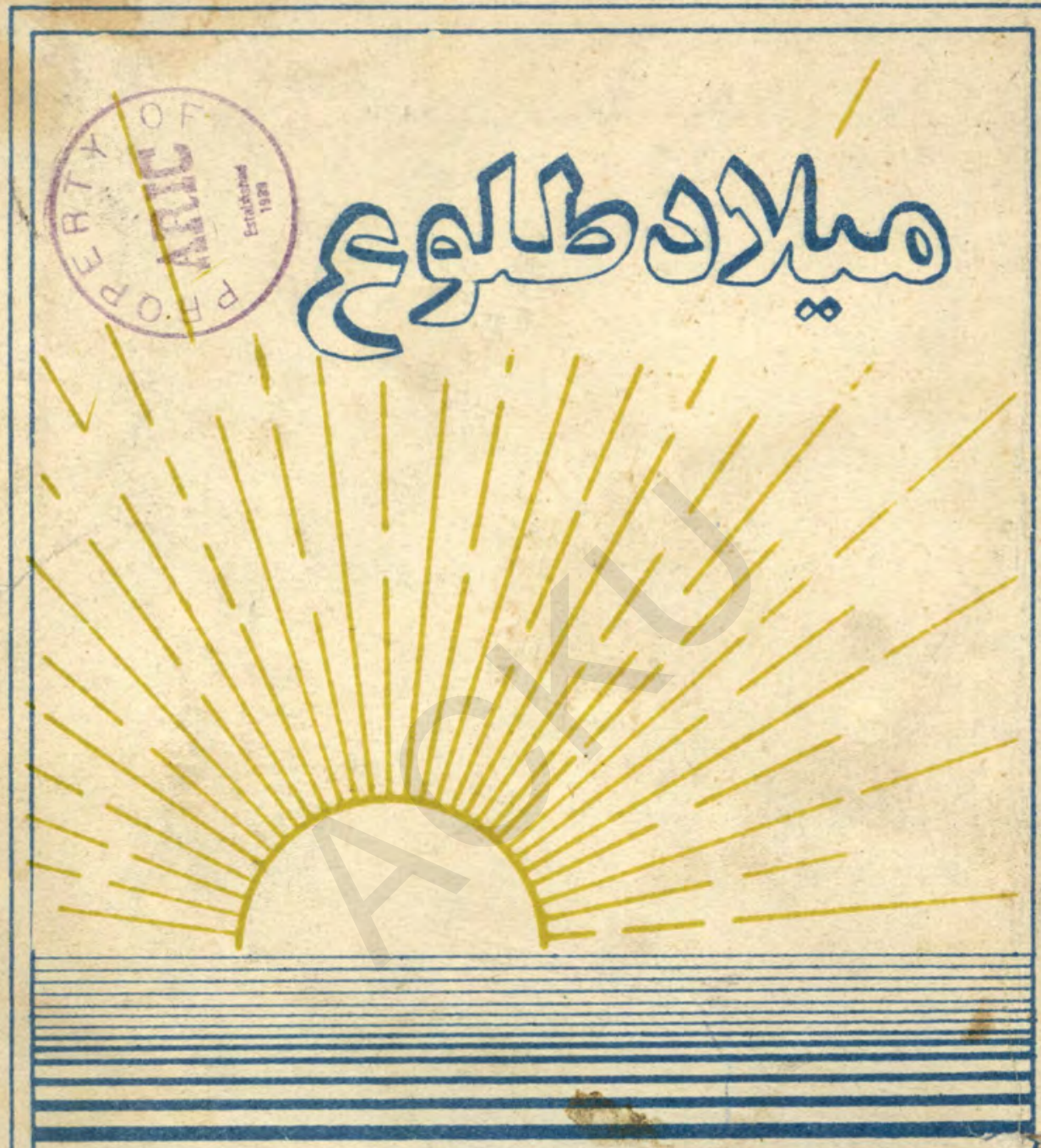


ميلاد طلو ع 
فضلحق فكرت

calboy

ACKU

دفتير شعر

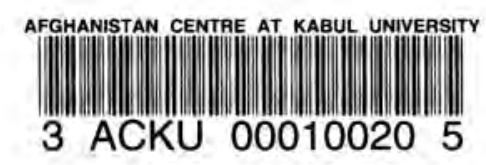




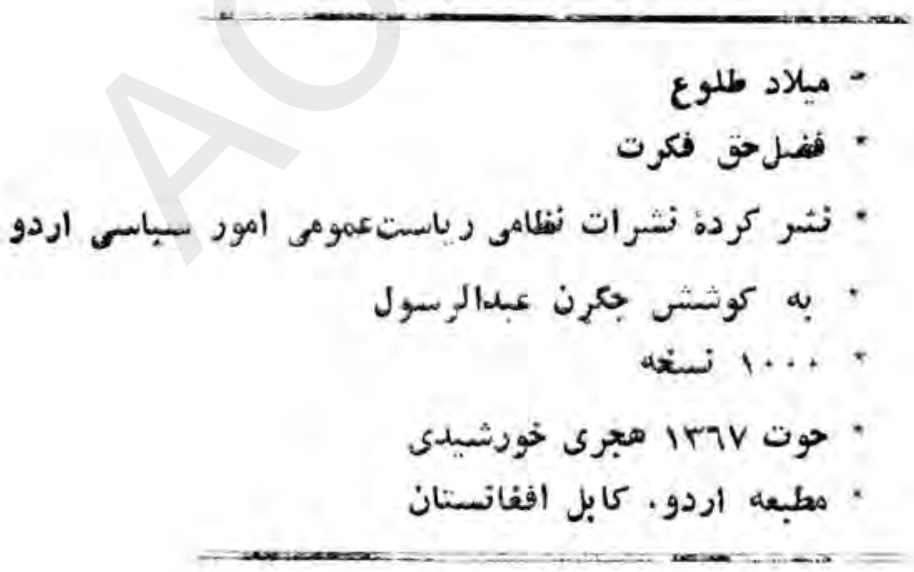




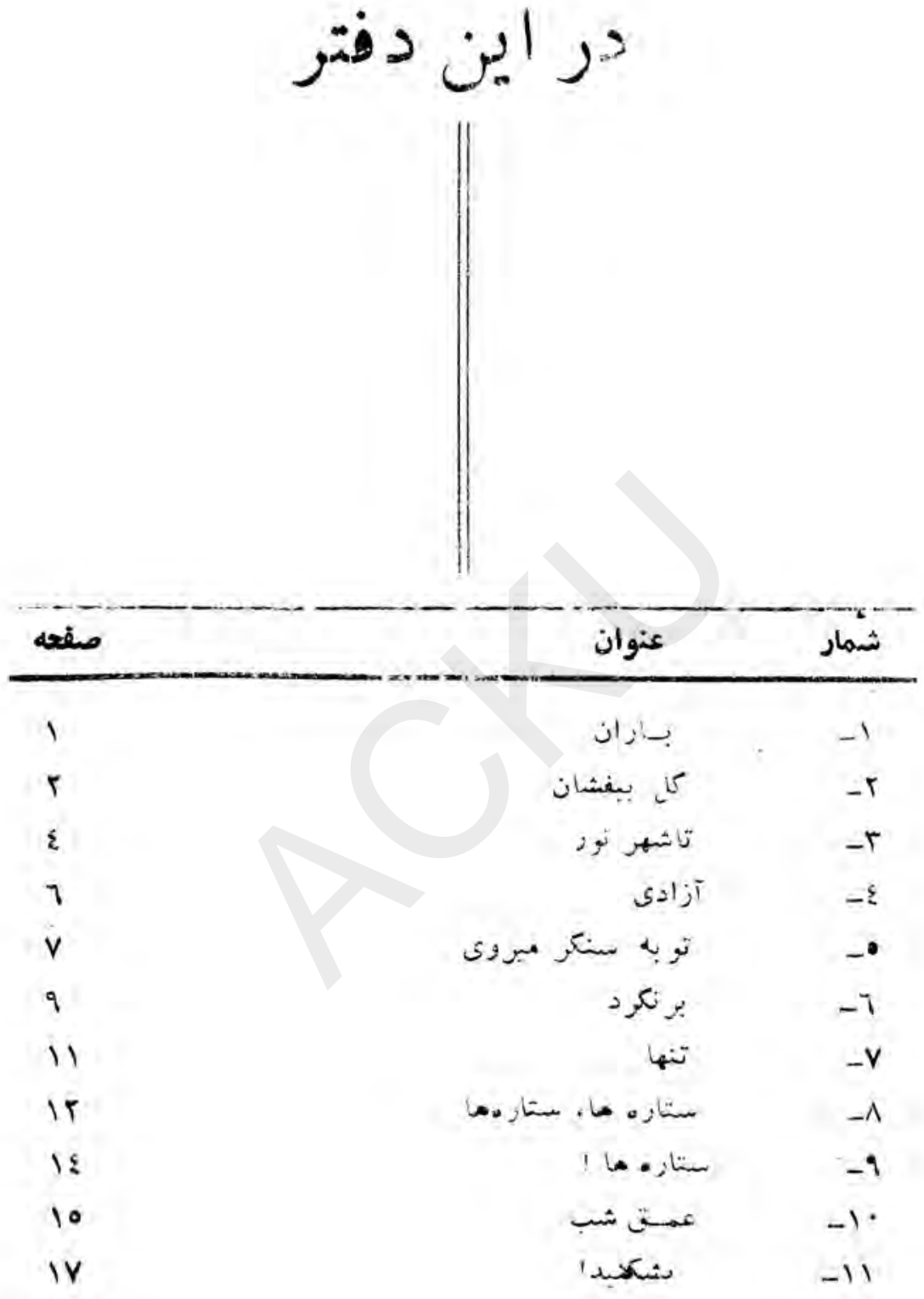




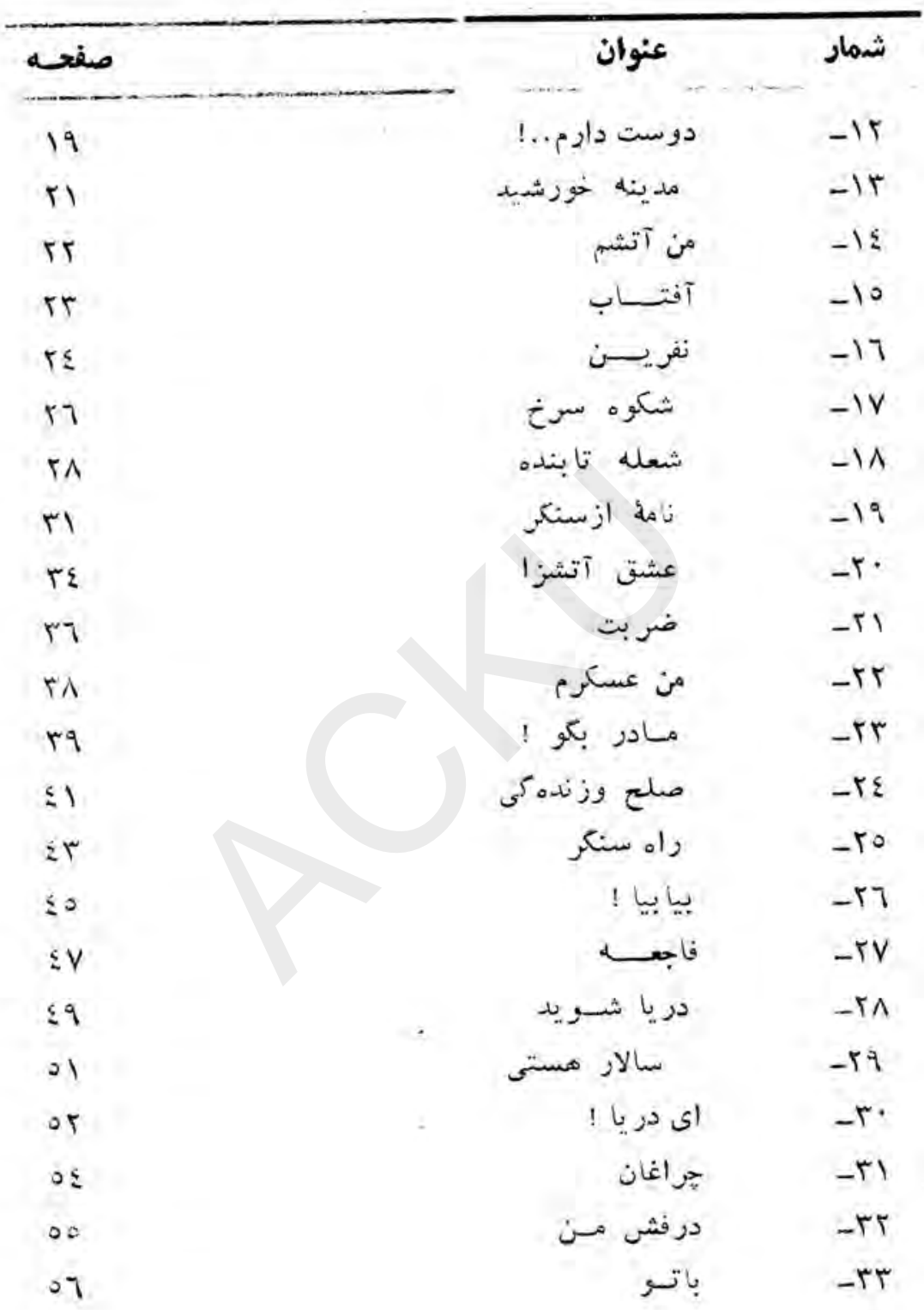




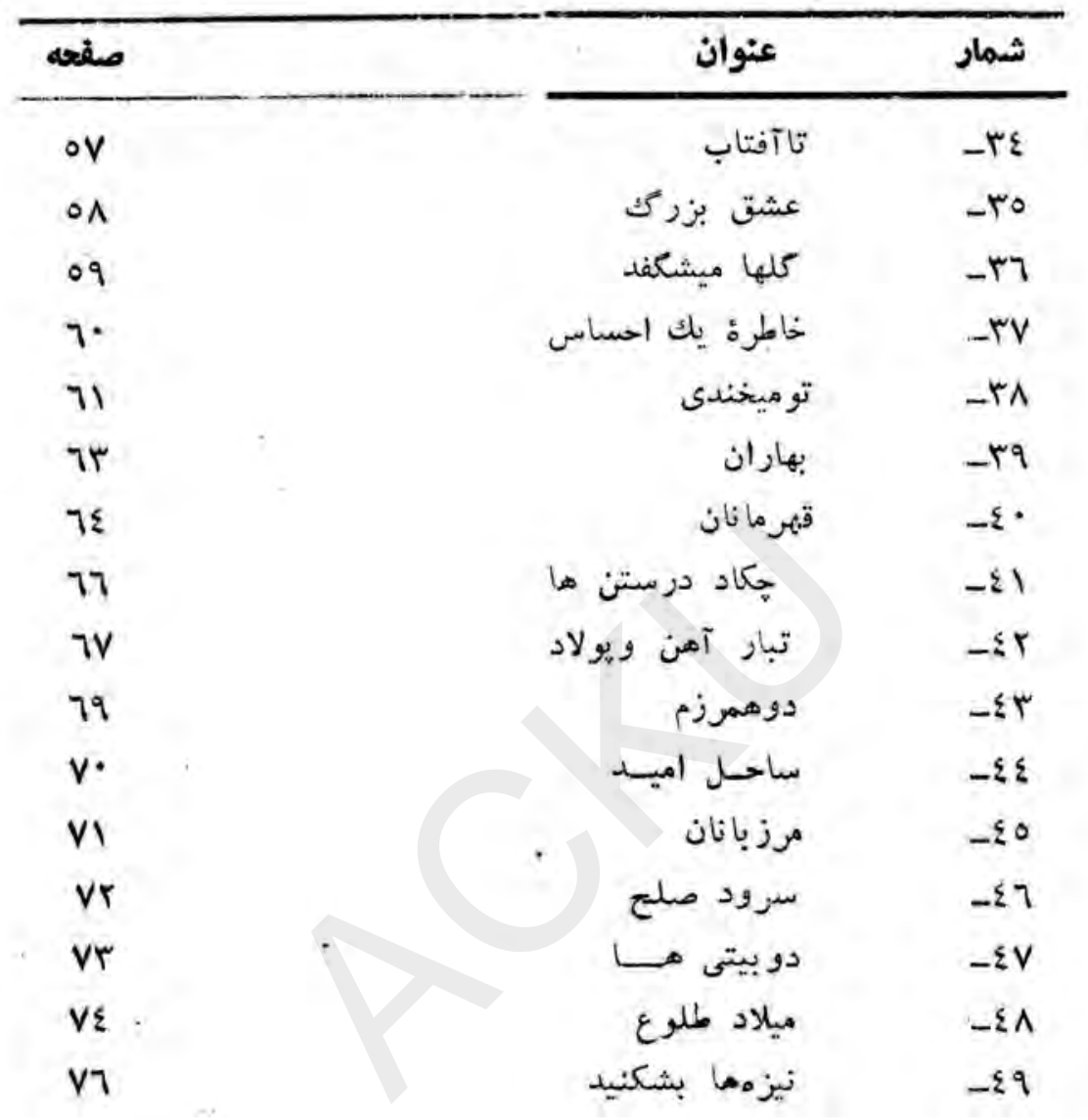




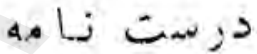

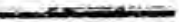

قبل ازخواندن تصنيحات ضروركرا بايد برنظر كرفت .

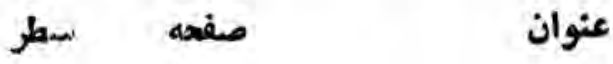

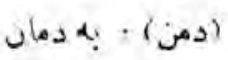
111
بارن
(1) (1) ) حذف شود )
$\mathrm{r}$
$\mathrm{V}$
شكوه سرخ
(همعزم) به مهرزم
$\checkmark \quad r y$
ضر بث 


\section{il (3)}

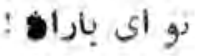

نشاطستى

$$
\begin{aligned}
& \text { بهاران دأ بو بلد ستى } \\
& \text { اعيدستى }
\end{aligned}
$$

دمر سيراب كن سيراب

بنخوان امووز تشعر آب

زتسو -

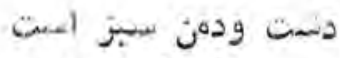

زمين سبزو زمان سبيز است

جهان نا جاودان سبز اسمت سمان

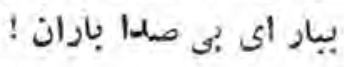

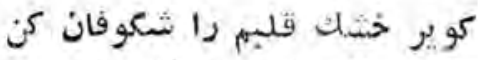

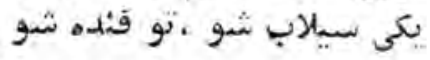

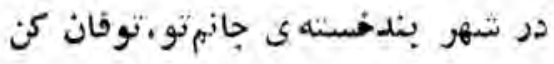

$$
\text { تواى باران : }
$$

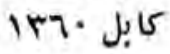

[1] 


$$
\begin{aligned}
& \text { Uisises } 5 \\
& \text { طولم " يكباد ديكر } \\
& \text { لز لكير وكل بيفتنان } \\
& \text { دنتب هارا. كن هيزائان } \\
& \text { از تسر أب كطر سادى } \\
& \text { كاز ه } 5 \text { كائدان جان را }
\end{aligned}
$$

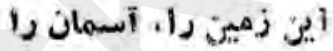

$$
\begin{aligned}
& \text { اي تشر اب كشف ميهن : } \\
& \text { هيت كن جان ونتم ردا } \\
& \text { ركت ركم سيراب كي } \\
& \text { تاكه كردم مسبت و رقصان }
\end{aligned}
$$

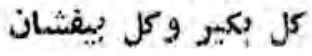

$$
\begin{aligned}
& \text { ساقيا بزم نشاطن } \\
& \text { جزم ثنادى أقور ينت فئت } \\
& \text { جشن ميخك هاى عشقت } \\
& \text { نور عشق آفتاب } \\
& \text { آفتاب انقلا بت آتاب }
\end{aligned}
$$

[r] 


$$
\begin{aligned}
& \text { ? }
\end{aligned}
$$

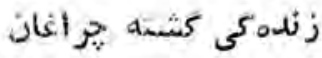

$$
\begin{aligned}
& \text { كل بكيرو كل بمقنسان } \\
& \text { 3أ سورو نستى } \\
& \text { أسن جر اغارن } \\
& \text { نامده الند ركف نو } \\
& \text { آنقدر ها مغنت وآسان } \\
& \text { آنقدر ها مفت و آسنان } \\
& \text { خائه أت ران } \\
& \text { 1, تina } \\
& \text { هادر جان وتشت ران } \\
& \text { كل جلمامانشى نكر دند } \\
& \text { مغت وآسان : } \\
& \text { جلجر اغانشى ثكر دند }
\end{aligned}
$$

الين :هاران لاله هاي دثشتو دامان

$$
\text { سبزو سرخ اين كلستان }
$$

جلجراغ آرزو هاست

$$
\text { الن جهان شادو خندان }
$$

إز فو

$$
\begin{aligned}
& \text { نار ها كشتى رها : } \\
& \text { أز حاه ظارهت تمثت } \\
& \text { جان ها كرديد قرديد } \\
& \text { درد ها كرديد درماز } \\
& \text { برهز ار قهر مانان } \\
& \text { كل بكبرو كال بيفشان مانان }
\end{aligned}
$$

ixา נ1, נx= fis 


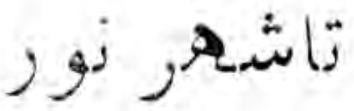

$$
\begin{aligned}
& \text { هن آهنم بهن آهنمي } \\
& \text { سر باز خاك ميهنم } \\
& \text { خواهم اكر توفان كتم } \\
& \text { بنياد ظلمت راهمه } \\
& \text { از بيخ و بن وير في واهمه كثم }
\end{aligned}
$$

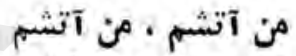

$$
\begin{aligned}
& \text { من همجيو موج سر كشم من آثن }
\end{aligned}
$$

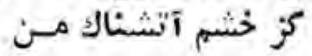

$$
\begin{aligned}
& \text { سوزد زمين }
\end{aligned}
$$

سوزد زمان

$$
\text { اقسرده } 5 \text { مارا برد }
$$

سمابل Aن ،در بأب هن

$$
\text { ايمان خارايين من }
$$

توفنده وبالنده است

$$
\text { همجون جراغ آفناب }
$$

دنباى من نابثد. اسه

$$
\text { دنب يكى كلشن شهون دوشن شود }
$$




$$
\begin{aligned}
& \text { من جلجِرأغ آفقتاب } \\
& \text { هن آفناب النقاب الغاب }
\end{aligned}
$$

$$
\begin{aligned}
& \text { من آنش توفنده ام } \\
& \text { اى رهنورد :أى همنبرد : } \\
& \text { بامز بمان ، بامن بندوان همنير }
\end{aligned}
$$

$$
\text { اي كارك : اي برز5 : }
$$

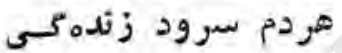

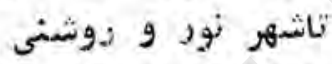

نا خطه تابنده تور

$$
\begin{aligned}
& \text { آنجا كه دوح زنده } 5 \text { كي }
\end{aligned}
$$

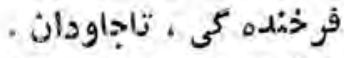

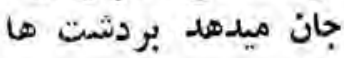

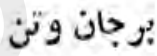

برمزو بوم اين وطن

هستى شكوقان ميشود

$$
\text { تا تاودان }
$$

ST 


$$
\sin ; T
$$

دوغ آزادى .اسير ينجه ىصبادبود

شوق هستى ، كثته ساطور استبداد بود

ناله هاى يمكنا هان در كلو بيجيدومسيرد

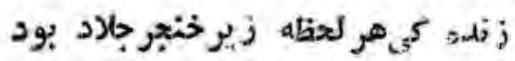

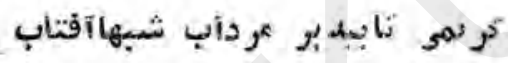

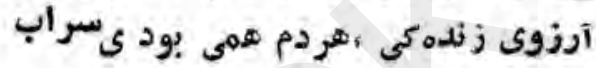

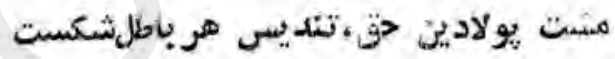

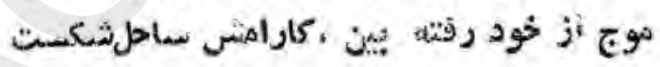

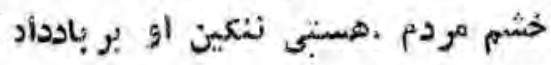

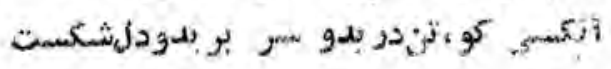

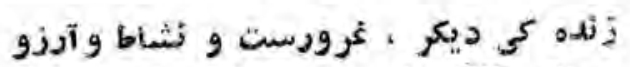
صنه آزأده كي وحلو

كإ.

[1] 
توبهسيُكُ هيروى

$$
\begin{aligned}
& \text { من بر' بروردم الم } \\
& \text { مث ترا جان داده احـ } \\
& \text { اي نهال زندم: }
\end{aligned}
$$

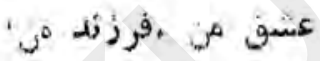

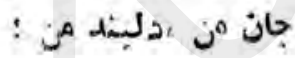

جاذ كرقتى .أى يسر :

تاشثلى ثيروى من

تا شمدى بازوى مز من من

توبه سمنكر ميروى

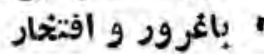

من زمستى بى قور افتئار

رانكه هستىاينوطن داباسه اد

[V] 
تو برو فرزنلهن ؛

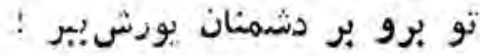

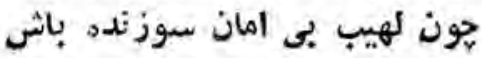

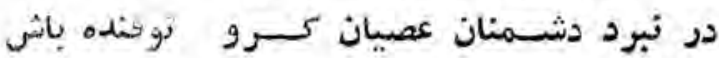

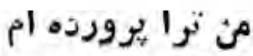

اي اميد جاودان : برون

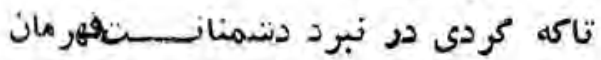

افتخار اين وطن نيروى نست

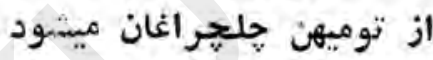

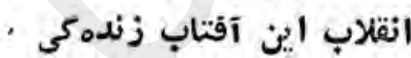

از تودوشن از توتابان ميشود إنئ

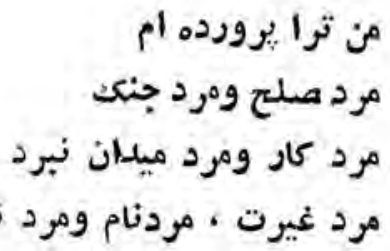

كابر بارتر+7rا 


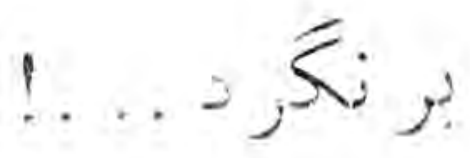

تو برو، سربائز من ؛

ائ جوانمرد زمان : أرون

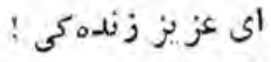

ائ غرور جاودان :

تو برو قوز

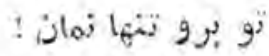

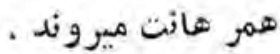

در نبرد دشتمان

دشمنان إين وطن

دندمنان جان و و تسنان

$$
\begin{aligned}
& \text { من ترا إبروردم إم }
\end{aligned}
$$

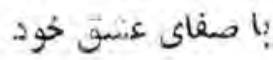

$$
\begin{aligned}
& \text { تاتو دوزي ،اي جوان : }
\end{aligned}
$$

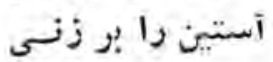


دشمنان را سرزنى

$$
\begin{aligned}
& \text { توبرو دلبيند من ! } \\
& \text { در نبرد اهرمن } \\
& \text { در شرار كار زار } \\
& \text { تا جهان زنده كـى تصى } \\
& \text { از تو كردد جون بهار }
\end{aligned}
$$

$$
\begin{aligned}
& \text { زود شــــ : } \\
& \text { سروبازمن : سون } \\
& \text { همر هانت ميروند . حوقي } \\
& \text { جوقه ،جوقه در نبرد } \\
& \text { تا نكوبى سنكر إهر يمثان } \\
& \text { يإي } \\
& \text { جان من تو برنكرد : } \\
& \text { تاكه بينم در وطن } \\
& \text { رويش كلهاى صلح }
\end{aligned}
$$

افتنار جاودان

$$
\begin{aligned}
& \text { كر تو بوكردى زراه }
\end{aligned}
$$

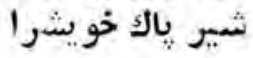

$$
\begin{aligned}
& \text { هن نمى إخشير به تو } \\
& \text { تو مو امكادر مكو ؛ } \\
& \text { تومرا مادر مكو : مادر مكو ؛ }
\end{aligned}
$$

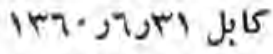




\section{a.}

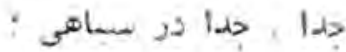

$$
\begin{aligned}
& \text { عروب ميكني }
\end{aligned}
$$

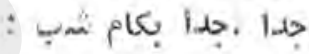

$$
\begin{aligned}
& \text { رنسوب مينى } \\
& \text { ! w } \\
& \text { نتها مكن سفر } \\
& \text { ! as . of } 9 y^{\circ} 6
\end{aligned}
$$

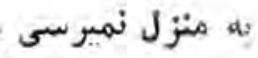

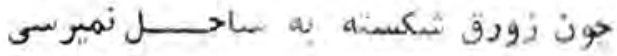

$$
\begin{aligned}
& \text { تنها - }
\end{aligned}
$$

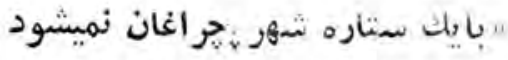

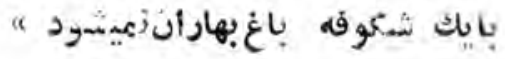

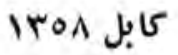

[11] 


\section{! loo jum}

\section{! loo jow}

بو كودمتشت

+

سارئ

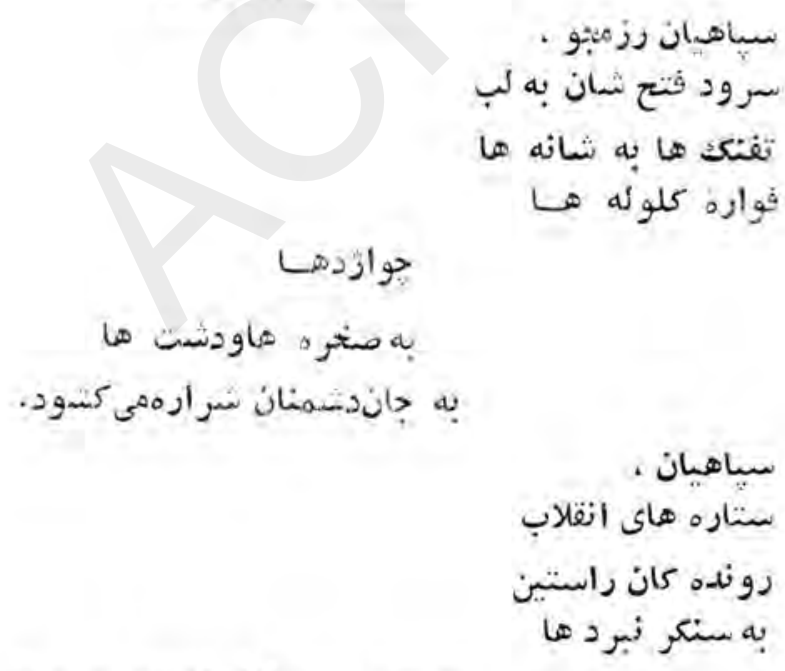

به سوى دشمنان نشائه مبروند 
5ه a تاكبوتر صفاىزنده5ى ،

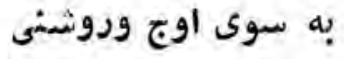

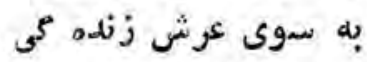

$$
\begin{aligned}
& \text { به سوى نور آرزو }
\end{aligned}
$$

مدام بالووبرزنثد.

ستاره ها! ستارهها:

$$
\text { دلاودان انقلاب : }
$$

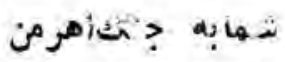

به جان دشمن وطن

يكى شراره ميشويد

درآسمان افتخار اين وطن

به دفتر زماثه ما بكن

يكى ستاره ميشويد

فروغ جاودانه ميشويد

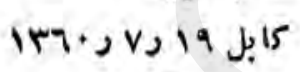

[ir] 


$$
\begin{aligned}
& 1+\operatorname{lis} 3 \text { jow } \\
& \text { متاره ها مي درخشنئل } \\
& \text {. بهناى آسمان } \\
& \text { نابيكر ان } \\
& \text { زرفشان ميشود } \\
& \text { متاره ما مي درخشند } \\
& \text { وما ندكار مسندونـ } \\
& \text { تاحاودان } \\
& \text { توسشتاره يسى }
\end{aligned}
$$

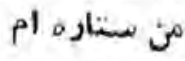

$$
\begin{aligned}
& \text { توو م-ن } \\
& =1050 \text { a dao }
\end{aligned}
$$

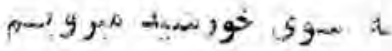

$$
\begin{aligned}
& \text { وجاودأنه مششويم } \\
& \text { irq. JA, jo ju }
\end{aligned}
$$




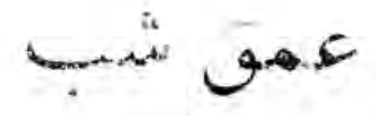

به دنشت هاى بـ بهار ،

به خاره زار

به دنشت هاى ب, برزنيك

به "كمي" هاى بـ و وقار

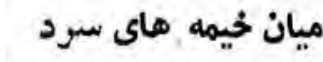

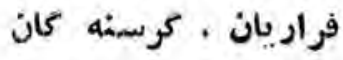

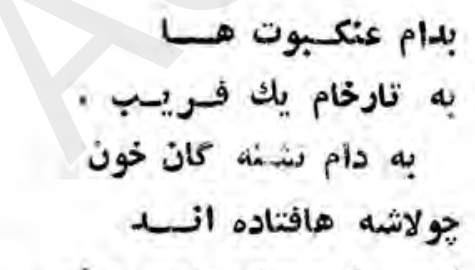

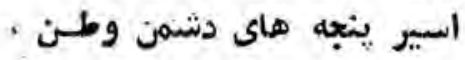

فناده رخش بخت شـان

به زير تازيانه هـ

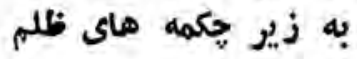

به حشم هابه حهره هـ

[10] 


$$
\begin{aligned}
& \text { سكوت مركبار غسم } \\
& \text { غروب آفتابززنده فى فرارسيدهأنديثي } \\
& \text { بوراريان · ·رمنكان } \\
& \text { زوحشت شب سياه }
\end{aligned}
$$

هكى دلث شكسته اسمت

يكى به خون زشمسته است

? سوى سر زوثمت شوم

بـ جعر حاه

به عمق شب

به سوى باتللاق هركتميروند ،

$$
\text { كابز •أری • • }
$$




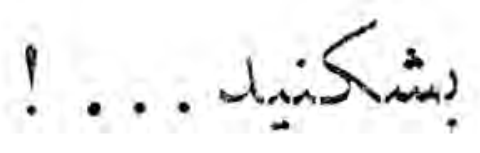

$$
\begin{aligned}
& \text { سرنيزه هارا بتسكنيد : } \\
& \text { الى رفته كئ درعمق شب؛ }
\end{aligned}
$$

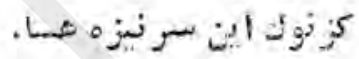

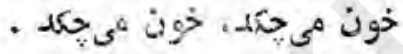

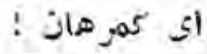

$$
\begin{aligned}
& \text { نيروى ها : نمات }
\end{aligned}
$$

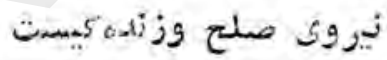

$$
\begin{aligned}
& \text { بالند } \\
& \text { نيروى تو: } \\
& \text { اهر يمنيست } \\
& \text { زيروى جنك وبنده كيست } \\
& \text { نيروى ج:كت وتيرهكى } \\
& \text { نيروى صلح و بإهمى جنى وني }
\end{aligned}
$$

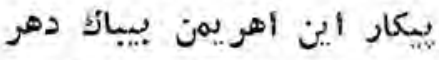

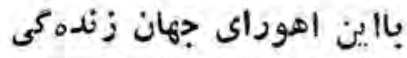

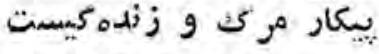

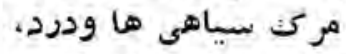

$$
\begin{aligned}
& \text { مركى شر شراد جنكـها، }
\end{aligned}
$$

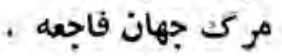

[iv] 


$$
\begin{aligned}
& \text { صلح وصفاى زنله كيست }
\end{aligned}
$$

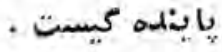

$$
\begin{aligned}
& \text { تعرئز هارا بشكنيد : } \\
& \text { تاعاشقان أين وطز } \\
& \text { اين مرد وزنذ } \\
& \text { باهـــ رون } \\
& \text { تاراوج ;تسمور } \\
& \text { ناكهكشان }
\end{aligned}
$$

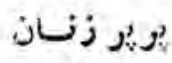

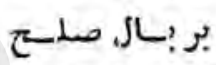

$$
\begin{aligned}
& \text { تا جــان } \\
& \text { تابيكران } \\
& \text { سرنيز عا را بـكنيد : } \\
& \text { اي كمر هان : }
\end{aligned}
$$

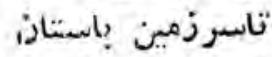

$$
\begin{aligned}
& \text { اين مهاند بالك قهر مان }
\end{aligned}
$$

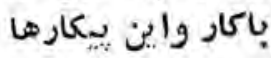

$$
\begin{aligned}
& \text { زيبا ثودو، زيبا ثشود } \\
& \text { جون كلشن دنيا ثرود } \\
& \text { سرنيزه هارا بشكنيد : }
\end{aligned}
$$

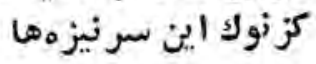

خون هنحيد ،خون مي حكد

ra. 


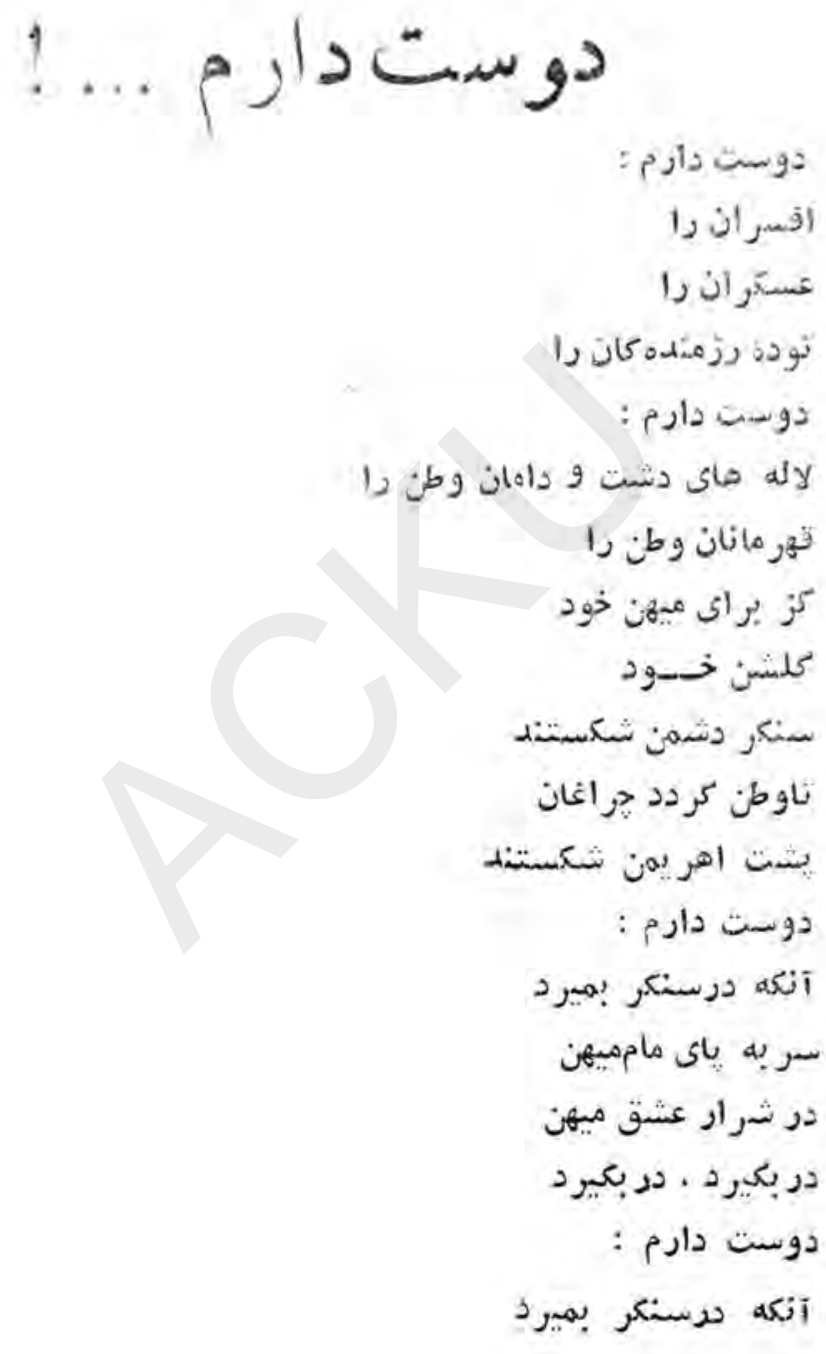




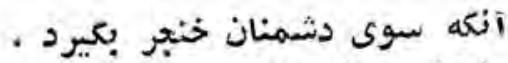

$$
\begin{aligned}
& \text { بشكئد ديوإنهار } \\
& \text { برج و باروى ستميندا }
\end{aligned}
$$

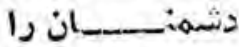

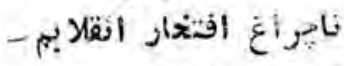

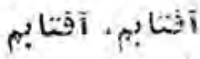

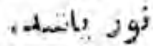

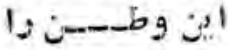

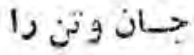

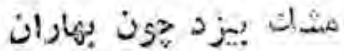

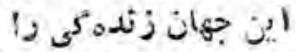

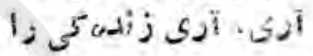

كإ 


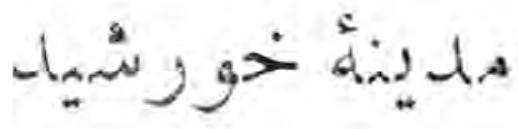

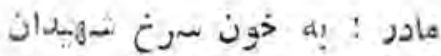

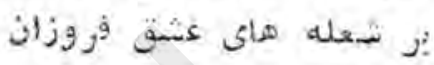

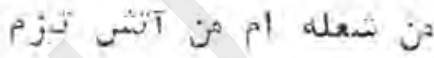

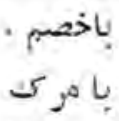

باديو ودد، جون رستهم دستان

بادنسمنى ذبون بيستيز مدون

مادر : درفش اين وطنم را

اين افتجار جان وتنبم دا

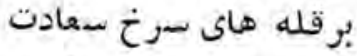

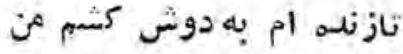

تازنده ام زكف نكذارم امن

IrTo/E/TV Jo

هن در ديار صبح سيبده.

بامشعل مدينه خورثيد

با هاله زنور مقدس مد بنه

سازم حو آفتاب فروزان [ri]

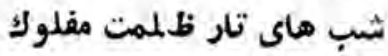




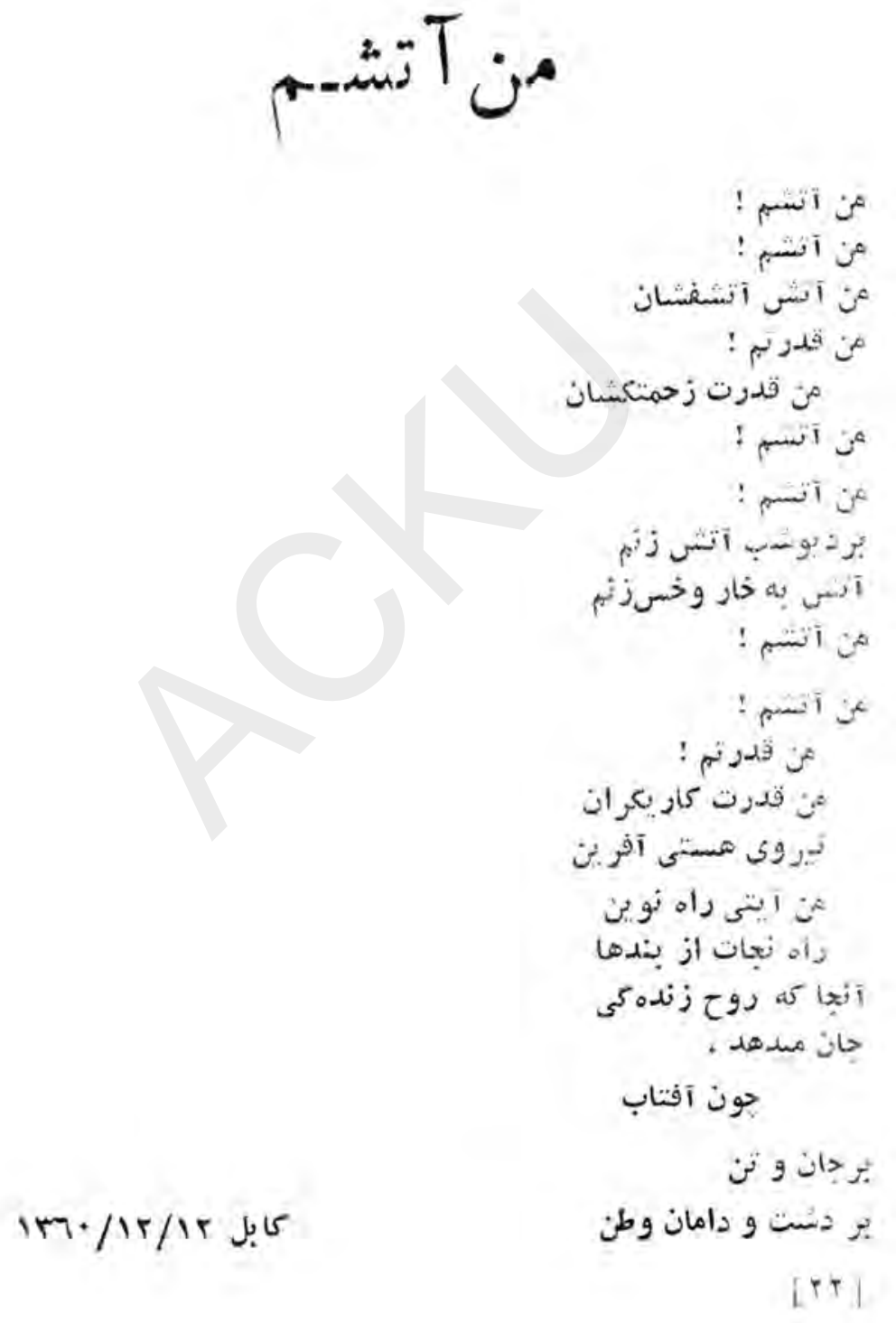




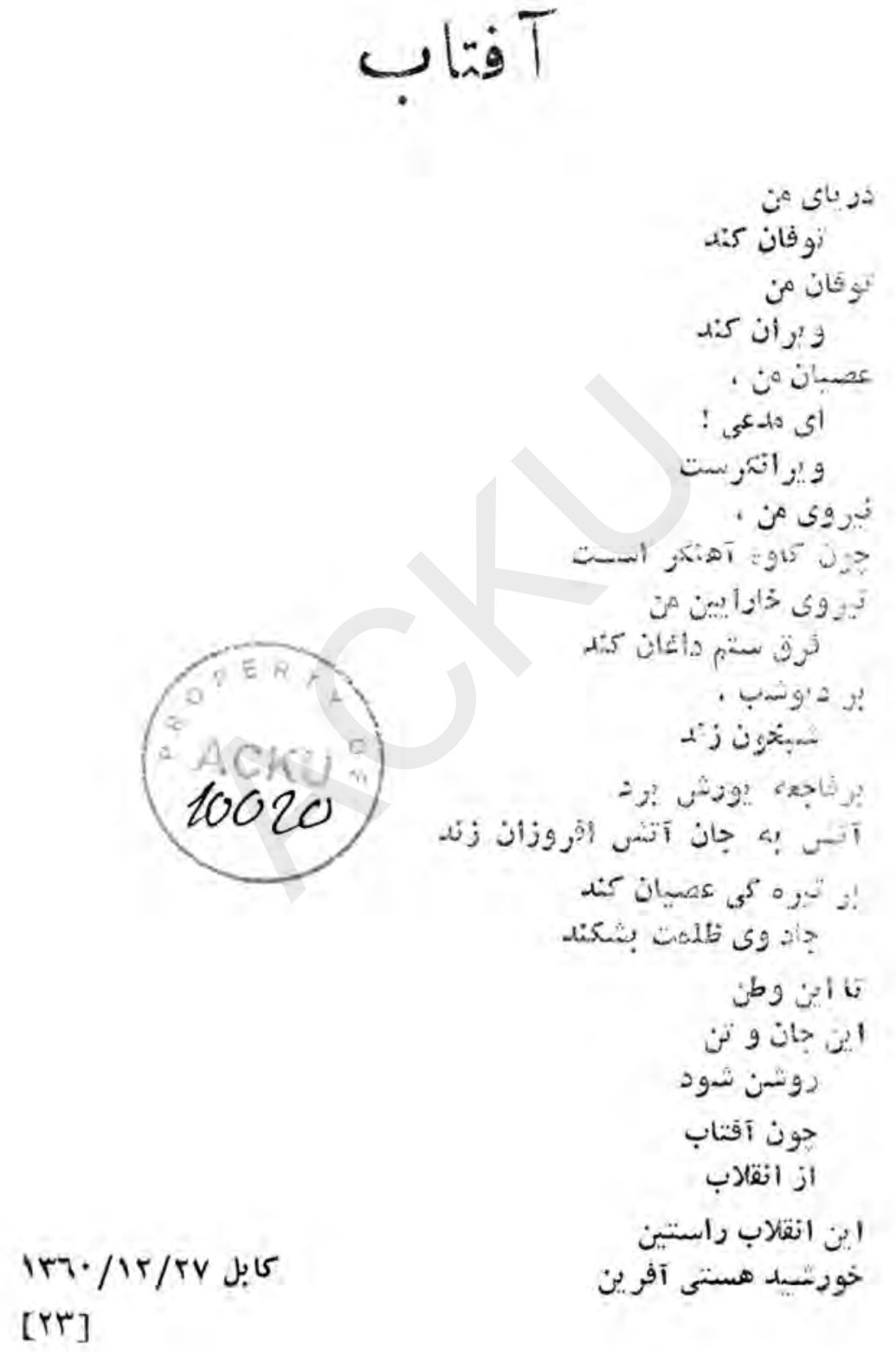




$$
\begin{aligned}
& \dot{0} ;
\end{aligned}
$$

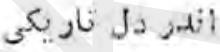

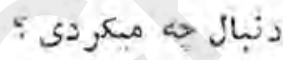

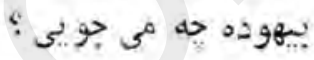

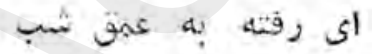

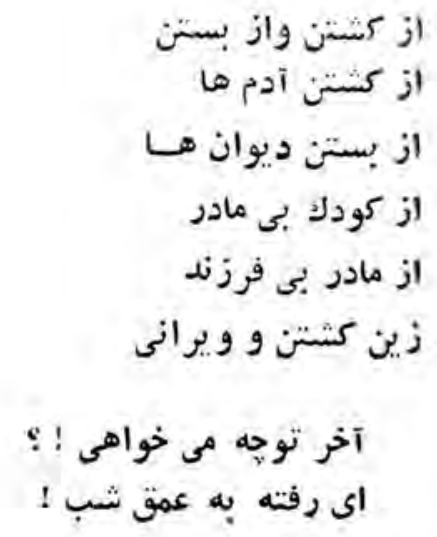




$$
\begin{aligned}
& \text { اندر دل تناريكى }
\end{aligned}
$$

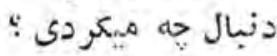

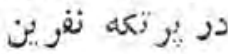

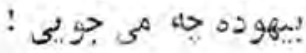

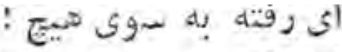

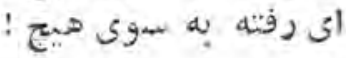

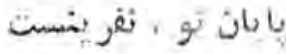

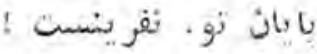

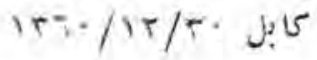

[YD] 


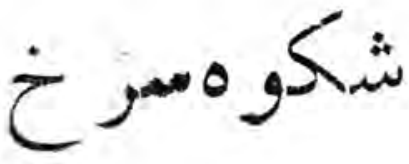

:

تو جاودان بمان : بان

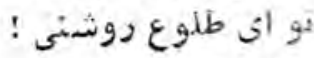

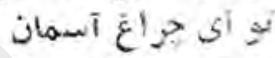

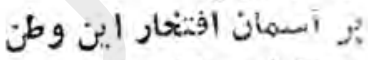

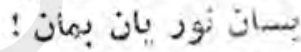
:

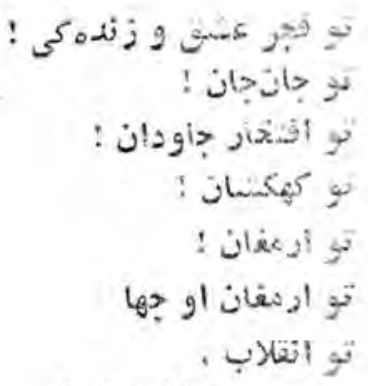

تو جأودان بمان : أنسان تو حلنجر أغ آفتناب تو بأ غورور نوبا سترور خوموج نو نور به الوج نوج نور

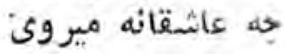
'تو مادقانه ميروي' 


$$
\begin{aligned}
& \text { بسوى نود آرزو }
\end{aligned}
$$

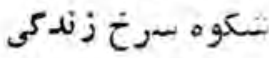

$$
\begin{aligned}
& \text { حه فاتحانه ميروى } \\
& \text { جه جاوداثه ميروى } \\
& \text { تو ثصل سبز زنده ني }
\end{aligned}
$$

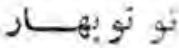

$$
\begin{aligned}
& \text { تو لاله زأر } \\
& \text { تو دلكشاى جستجو } \\
& \text { تو جلجِ اغ آدزو } \\
& \text { تو آفنتاب } \\
& \text { تو انقلاب }
\end{aligned}
$$

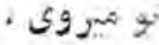

$$
\begin{aligned}
& \text { به آقثاب مى رنسى } \\
& \text { تو ماندكار }
\end{aligned}
$$

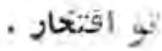

كايل 


$$
\text { O limbid }
$$

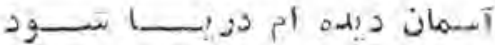

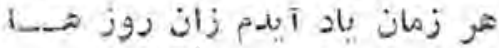

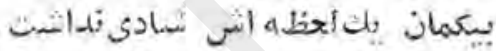

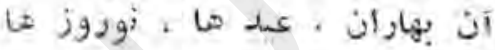

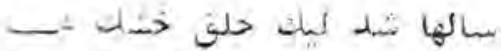

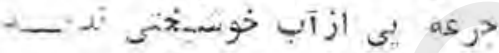

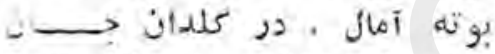

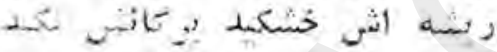

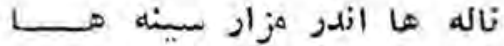

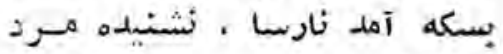

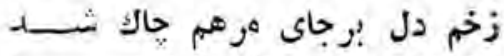

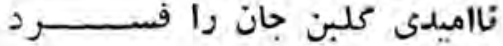

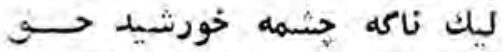

خون هستى در ركت جاتها

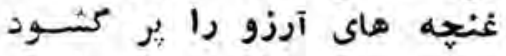

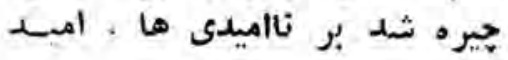


هزئو دبواز ستم بشكست ور بنّت

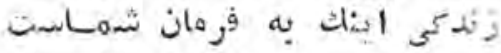

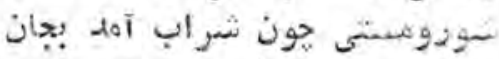

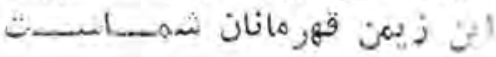

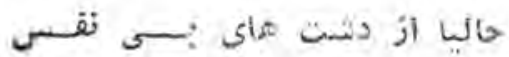

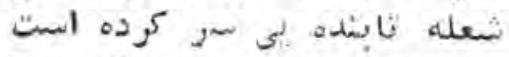

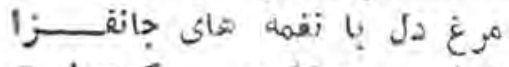

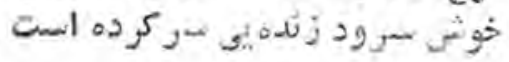

[ra] 


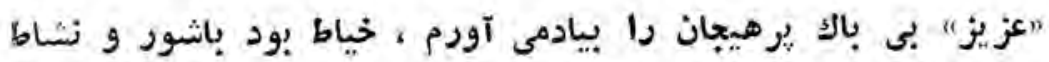

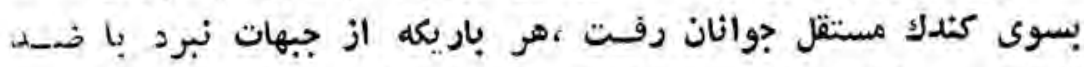

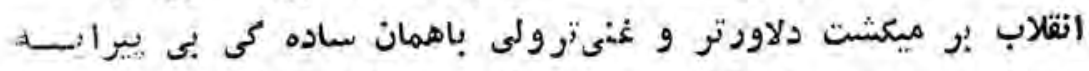

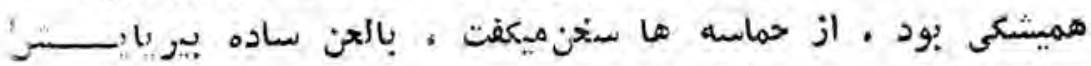

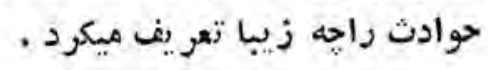

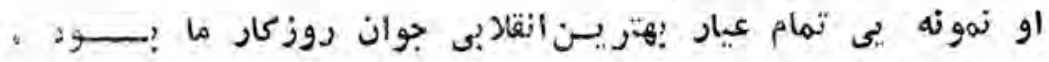

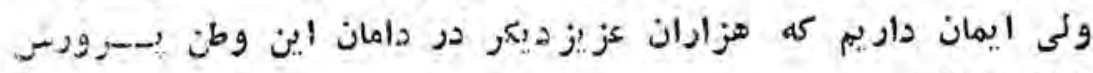

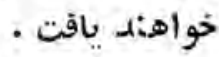

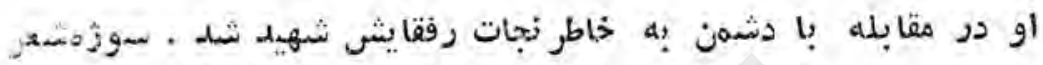

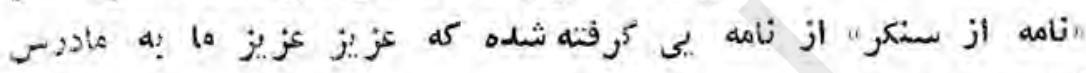
نوشته بود . 


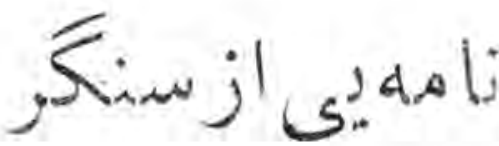

$$
\begin{aligned}
& \text { از } \\
& و^{\ddot{3}} \\
& و^{3} \\
& \text { م) } \\
& \text { (is, } 2,12 \\
& \text { ! نle }
\end{aligned}
$$

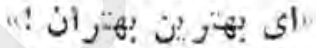

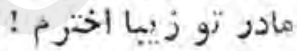

$$
\begin{aligned}
& \text { : } \\
& \text { أى از }
\end{aligned}
$$

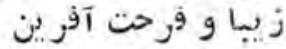

$$
\begin{aligned}
& \text { هر حنا دورم از رخت } \\
& \text { : Sll }
\end{aligned}
$$

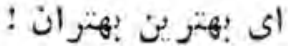

$$
\begin{aligned}
& \text { كرم است جون آغوش ثو }
\end{aligned}
$$

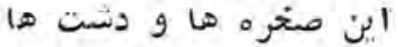

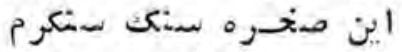

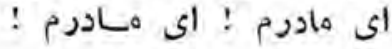

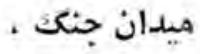

$$
\begin{aligned}
& \text { ! إن }
\end{aligned}
$$

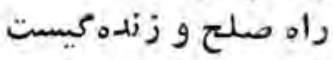

$$
\begin{aligned}
& \text { ؤرخنده كيست }
\end{aligned}
$$


الى جان مز :

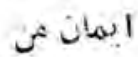

جار بست دو ركهاي هن

در جان و تن

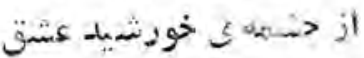

خمن ومن

مـــام وطن

$\frac{y}{3}$,

igi 34

عهبائ نوز نوز

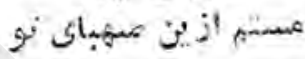

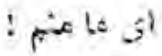

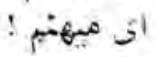

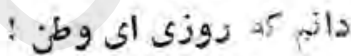
آييشه بندان ميشوى أوطن

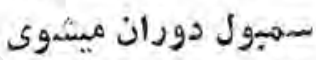
با، بهان ميوزي

مهين بهاران هيستود كلشن هر اغان ميشود

$$
\begin{aligned}
& \text { اندز بي أين آدزو } \\
& \text { ان ملدوم : } \\
& \text { ائ هادرم : }
\end{aligned}
$$

سفير بود بالين من مادم

كشي وطن آيين هن بالين

اين است درس انقلاب

اين است راه آفتاب

آتثى بزن برجان من :

$|r T|$ 


$$
\begin{aligned}
& \text { اى ميهنم : } \\
& \text { اي عشق من ! } \\
& \text { تا آتش سوزان شوم }
\end{aligned}
$$

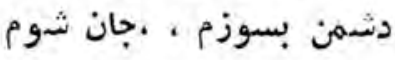

$$
\begin{aligned}
& \text { اي عشق من · درمان من ؛ } \\
& \text { اي راه من ايمان مسن هن }
\end{aligned}
$$

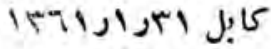




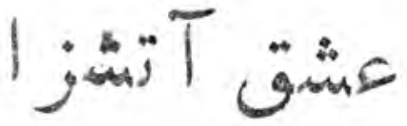

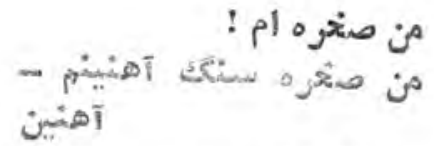

$$
\begin{aligned}
& \text { سر باز خاك ميفنم }
\end{aligned}
$$

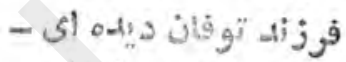

$$
\begin{aligned}
& \text { إن سر زميثم - } \\
& \text { سر زمين } \\
& \text { از آب آن ، }
\end{aligned}
$$

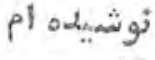

$$
\begin{aligned}
& \text { از } \\
& \text { plod. } \\
& \text { اكنون بهن } \\
& \text { إי- } \\
& \text { piolo } \\
& \text { اين مبهن هجبوب من } \\
& \text { أين مأم هن } \\
& \text { آغاز من ، انغجام هن } \\
& \text { اين سر زمين قهر مان من من } \\
& \text { يك عشق آنش زا شيده } \\
& \text { يك آتش عشق بز } \\
& \text { يك آتثى راه ستر كي } \\
& \text { [r } \xi]
\end{aligned}
$$




$$
\text { سوزد مرا }
$$

$$
\begin{aligned}
& \text { اين عثق هستى ساز من }
\end{aligned}
$$

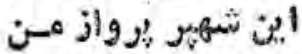

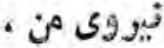

$$
\begin{aligned}
& \text { - }
\end{aligned}
$$

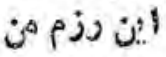

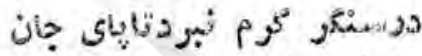
بأ

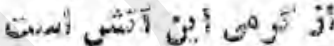

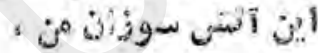

$$
\begin{aligned}
& \text { توقأن من }
\end{aligned}
$$

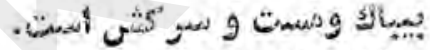

من آتش آتشفثشان

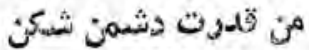

ن

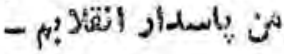

960519

$$
\begin{aligned}
& \text { هن دهثورد آَتنا بم أنمان } \\
& \text { تا سر زمين باستان } \\
& \text { اين ميهن محبوب من بن } \\
& \text { همجيون جراغ آسمان } \\
& \text { روشن شود } \\
& \text { تا بيكران } \\
& \text { كلشن شود }
\end{aligned}
$$

كابل

تاجاودان

[ro] 


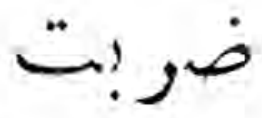

خاكت همه سبز جون بعارائ

ينجنير تومأ هـن دليــران

درياى تو موج خبز وجونشائ زيباست زمبن و كوهسارت

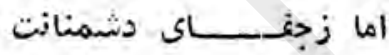

$$
\text { بلدا شده بود اين جهانت }
$$

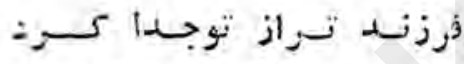

د بدى توكه دشمنت حها ها كرد

آنش زدو آتشى بيا كرد

بردي اروندار زنده كسى اتهن

$$
\begin{aligned}
& \text { هم عزم توكر فه هي نشدم مسـن }
\end{aligned}
$$

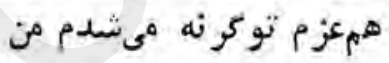

در جاه شب سياه :!سـودئ

ظلمتكاه ك:ــاه :-ودى

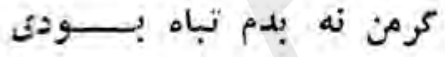

بنجشُبر بو ائ ديار شتيران

$$
\text { سرباز دليـر ايسن ديـارم }
$$

من دؤستمكران شكست

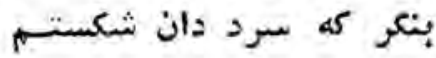

$$
\text { نيروى ركت نــرور مـردم زودم }
$$


بر دشمن قتشه كر بتـازم

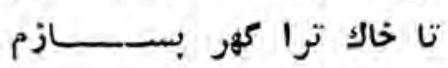

برباز توام كه سر بيازم

در راه وطن فـدا كنّم جان لـان

هردم زمن ومنم ز مهردم

اين جان وسرو تنم زمردم زمردم

كابل

(TV] 
قو انله سرباز

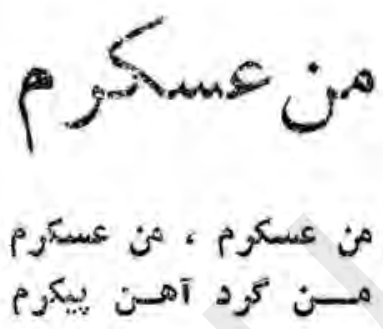

تيزوى هـن رويين تنســت

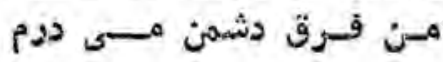

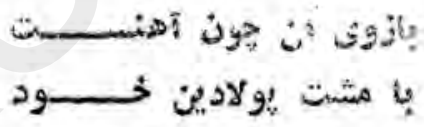

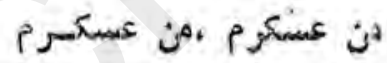

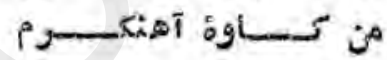

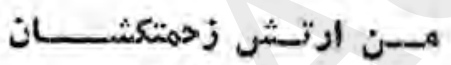

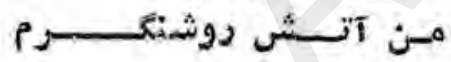

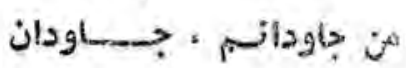

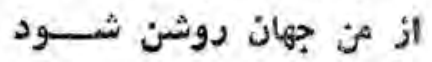

$$
\text { من عسكرم ، من عسكرم }
$$

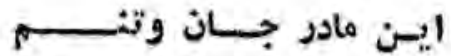

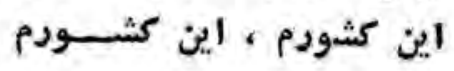

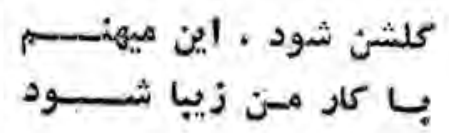

$$
\begin{aligned}
& \text { من عسكوم ، من عسكرم }
\end{aligned}
$$

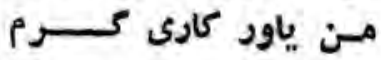

rim/ro

- [PA] 


$$
\begin{aligned}
& \text { مادر بكو!! } \\
& \text { مادز - }
\end{aligned}
$$

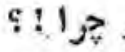

$$
\begin{aligned}
& \text { أي أشئ }
\end{aligned}
$$

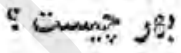

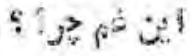

$$
\begin{aligned}
& 410 \text { p } \\
& \text { : }
\end{aligned}
$$

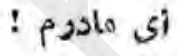

$$
\begin{aligned}
& \text { •أج سورم } \\
& \text { هنهيان مكن } \\
& \text { با خوند من } \\
& \text { كر يأن مكن } \\
& \text { آخر بكو } \\
& \text { أين أشكهايت - } \\
& \text { : } 9030 \\
& \text { أين غم جرا ؟ } \\
& \text { ماتم حرا بم } \\
& \text { از من ميرس من } \\
& \text { قرز منّد من ! } \\
& \text { اي جان من ؛ } \\
& \text { دلبند من }
\end{aligned}
$$




$$
\begin{aligned}
& \text { نوفان غم هايم همه + } \\
& \text { باران ثده } \\
& \text { از بيكران اندوه هن } \\
& \text { از إ.ر تار حسر تم } \\
& \text { از صنر ه هاى حشمه هي }
\end{aligned}
$$

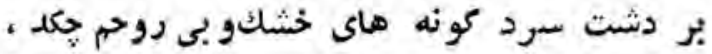

د.يوانه وار

اين قطر • هاي سوكوار مار

$$
\begin{aligned}
& \text { اين كر.يه ها } \\
& \text { اين الثك هـ }
\end{aligned}
$$

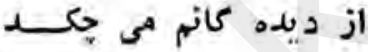

$$
\begin{aligned}
& \text { در ماتســـــم آن كمر هـ هـن }
\end{aligned}
$$

آناتكه در دام في ديب در جنكل خاموش تشب در دئ در حنكت آن سالوسيان

افتاده اند

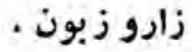

جون لاثشه هارو رون

در خمانه

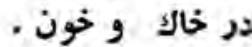

كا:J 


\section{صالحوز}

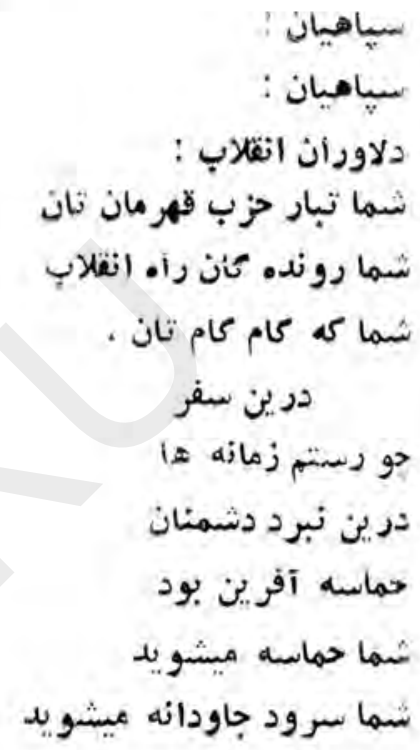

يكى ترانه مي نُو لذ.

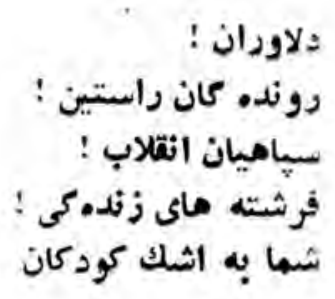


به ناله ها ومويه هاى مادران

يو ييك خنده ميشويد

$$
\begin{aligned}
& \text { له كوجي هـا . له }
\end{aligned}
$$

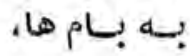

سياهيان :

قشون راه نوده هـا :

مبارك است :

:بهد تبان

نبرد تنان -

نسبرد مـرك و زنده كيست كيست

Im1/ 
Sinol,

$$
\begin{aligned}
& \text { - } \\
& \text { ز زعار من : } \\
& \text { رفته ز كف من }
\end{aligned}
$$

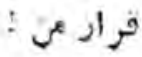

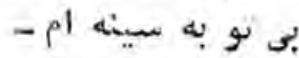

$$
\begin{aligned}
& \text { بيين } \\
& \text { ار درغم زبان كُشد } \\
& \text { شعله زند }
\end{aligned}
$$

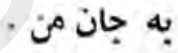

$$
\begin{aligned}
& \text { نامزدم : } \\
& \text { قصه زعشق من مكو } \\
& \text { سنتكر كرم دزم تو تو } \\
& \text { آتش عشق ديكر است روم تور } \\
& \text { كر تو دوى عثى } \\
& \text { به كار زار } \\
& \text { عشق مرا فزون كنى عار زوار } \\
& \text { عشق تو : عر : } \\
& \text { راه سنكر است تود تود }
\end{aligned}
$$

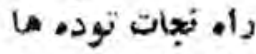

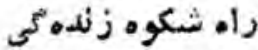

$$
\begin{aligned}
& \text { راء بهلر جاودان } \\
& \text { كلبشن عشق بـ خاه }
\end{aligned}
$$


: ثزئز مي

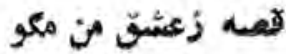

كشت وطن

ارا بكن

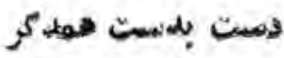

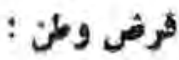

بيا بكن

ورونه مرا.

رها بكن

ثاعزدم :

$1 \mathrm{ral} / 0 / \mathrm{roj}$ Jus

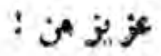

[: $]$ 
L)! L

هنور فريب دشمنان :

تو هموطن :

: ب.

به سوى دوثنى

زكام شب

بون بون

بيابيــا:

به خانه ات . ل.

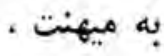

به لانه اته

كه خواهر و بوادرت لانه

هميشه درانتظارتست .

$$
\begin{aligned}
& \text { تو هموطن : } \\
& \text { تو اي ذبيح يك فريب ؛ } \\
& \text { يك يك دروغ } \\
& \text { ز دام عنكبوت ها } \\
& \text { ز زدام تشنه كان خون } \\
& \text { از عمق شب } \\
& \text { بون بيا } \\
& \text { بسوى روتشنى بـا } \\
& \text { بيا بيا : }
\end{aligned}
$$




$$
\begin{aligned}
& \text { تو هموطن }
\end{aligned}
$$

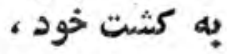

$$
\begin{aligned}
& \text { به كار خود }
\end{aligned}
$$

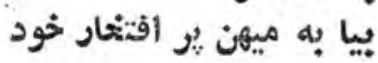

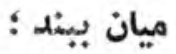

$$
\begin{aligned}
& \text { به كار ها } \\
& \text { تالاثى ها: }
\end{aligned}
$$

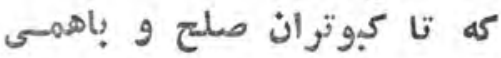

$$
\begin{aligned}
& \text { د به بام و }
\end{aligned}
$$

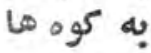

$$
\begin{aligned}
& \text { به دشت وكوه أين وطن }
\end{aligned}
$$

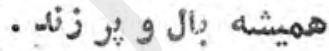

$$
\begin{aligned}
& \text { ! . } \\
& \text { تو هموطن ? }
\end{aligned}
$$

كا 
در سوكت شهيدان "صبرا وشطيلا)"

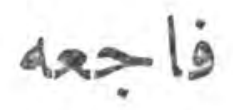

$$
\begin{aligned}
& \text { آملد بالابى بى امان } \\
& \text { كابوس موكت الأن } \\
& \text { جون إزدهاى تشنه خُونه } \\
& \text { غرق جنون } \\
& \text { جئكيز يان } \\
& \text { قاشيسيت ها: } \\
& \text { صهيونيان } \\
& \text { در خانه هأ و خانيان } \\
& \text { در جاده ها } \\
& \text { با ثيغ ها ها } \\
& \text { با آتتس باروت ها } \\
& \text { شبخون زدند }
\end{aligned}
$$

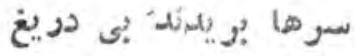

$$
\begin{aligned}
& \text { تن ها در يدند بـ دريغ: } \\
& \text { جاد هاد } \\
& \text { شياد ها } \\
& \text { صدها نقر } \\
& \text { صدها نفر } \\
& \text { از هردو زن } \\
& \text { از كودكان بى كناه } \\
& \text { از كودكان شير خوار بي }
\end{aligned}
$$

$[\xi v]$ 
در لاى دست مادران

با مادران

بهلوى مي مادرن

در خالك وخون

دادند جان .

أ فاجعه سازان قرن :

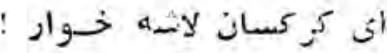

با وحتى خونتاى تان

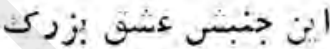

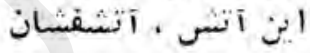

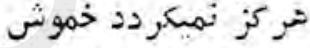

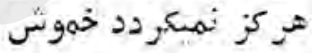

خلق فلسطبي هيحكياه

هركز نمى أفند زيا

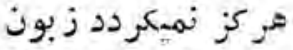

اي و و>نيان :

قاسمستس ها:

فأستست مانست

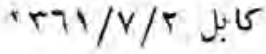




\section{دز ياشويد !}

$$
\begin{aligned}
& \text { أي } \\
& \text { اي مردو زن : } \\
& \text { بودش بر... بـ : }
\end{aligned}
$$

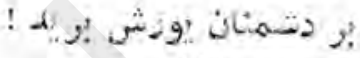

$$
\begin{aligned}
& \text { كأب } \\
& \text { إنز آنش أحروز'ن جنكت }
\end{aligned}
$$

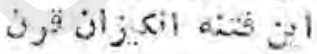

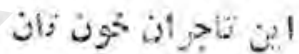

$$
\begin{aligned}
& \text { الير جائيان } \\
& \text { ائ زئروان كمق تشب }
\end{aligned}
$$

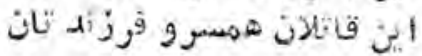

$$
\begin{aligned}
& \text { حلبند تان } \\
& \text { إين دهز نان }
\end{aligned}
$$

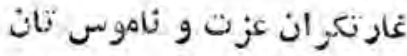

$$
\begin{aligned}
& \text { اين وحشت و كابوس زبـان } \\
& \text { ره ميزنتلـ . } \\
& \text { الما اكر اي هموطن ' } \\
& \text { دريا شويد } \\
& \text { توفان كنيد ، } \\
& \text { حون سيل هيبت ناك و هست }
\end{aligned}
$$


جر دشمثنان بورش بر يد :

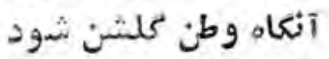
اهروز تان ، قردأى تان

از آقتناب انقلاب

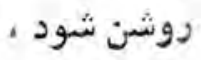

زوتشن شود .

$15+3 / 4 \cdot / 54$ y.5

$[2 \cdot]$ 


$$
\begin{aligned}
& \text { سالاردمتى } \\
& \text { ن ف فروغ آسمانتي }
\end{aligned}
$$

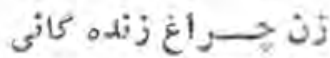

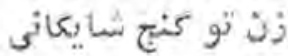

$$
\begin{aligned}
& \text { زن } \\
& \text { زذن جهان مهر بانى نانى }
\end{aligned}
$$

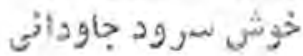

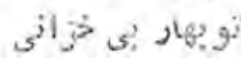

$$
\begin{aligned}
& \text { افتخار جاودانى ني }
\end{aligned}
$$

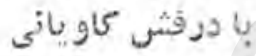

$$
\begin{aligned}
& \text { (t) } \\
& \text { قور مان ميبرودانى }
\end{aligned}
$$

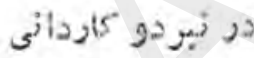

$$
\begin{aligned}
& \text { زن نه تنوا باغبانى كاردي }
\end{aligned}
$$

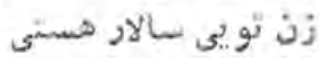

$$
\begin{aligned}
& \text { زن مقلدس مادرى تو تو لور }
\end{aligned}
$$

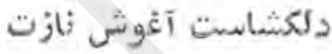

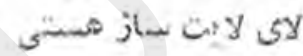

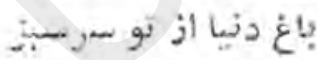

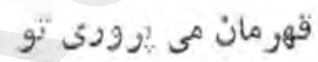

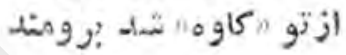

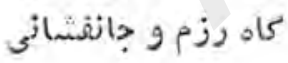

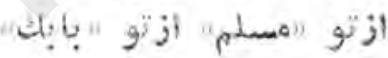

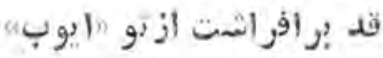

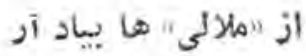

$$
\begin{aligned}
& \text { زن نه تنهها مادرى "و }
\end{aligned}
$$

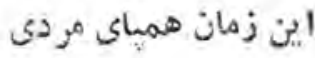

$$
\begin{aligned}
& \text { خامه از وصف تو عاجـز }
\end{aligned}
$$

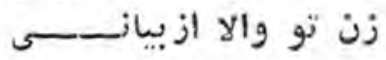

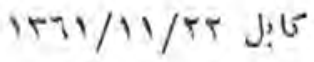


ائدريا ! إن

توا من دونست ميد'رم

ترا الى دزيا :

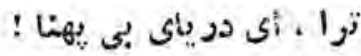

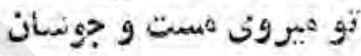

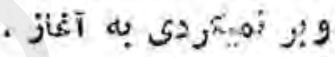

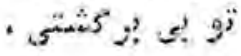

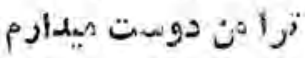

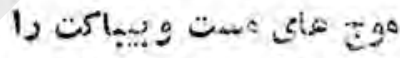

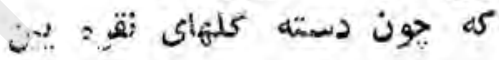

بك روى صنره ها ما سله

وإنشان ميثنوى

ودر بستر سنت زمين

در قلب كوه 10

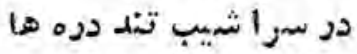

سينك مى سابيحي

وبر زخم دشيت هاى سوخته

جون زوشدار و اعجاز ميكنى

وتشنه كان زمين را ـأ.

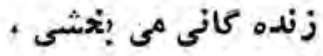

تو اي دريا !

[Di] 


$$
\begin{aligned}
& \text { جى خستكى ، با صغره ها هـــيتيزى }
\end{aligned}
$$

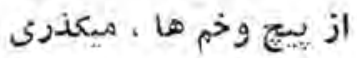

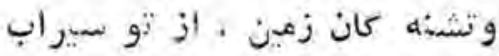

$$
\begin{aligned}
& \text { 政 } \\
& \text { - زمهن }
\end{aligned}
$$

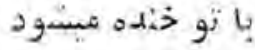

$$
\begin{aligned}
& \text { باغٔها و دششت } \\
& \text { ر شكوفه ميس3ود } \\
& \text { تو فصل سبز .رارانى } \\
& \text { زو درانئ + } \\
& \text { ترا هن دوست هيدإرم } \\
& \text { "راي دريا : }
\end{aligned}
$$

ك. 


\section{جان}

كو بهاران ميرسد ،

كاروان لحظكه ها در موج كل

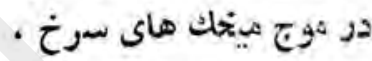

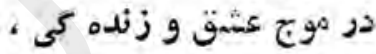

باتنده كى -

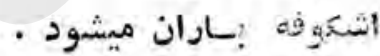

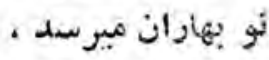

جثمهاء نسار آسمانى

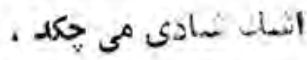

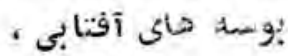

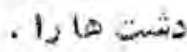

كو

12 , 129

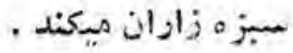

نو بهازان مبرسد

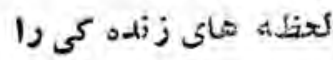

خوثل حر اغان ميكند مائ زئد

كוبل • 


$$
\begin{aligned}
& \text { نs vis jo }
\end{aligned}
$$

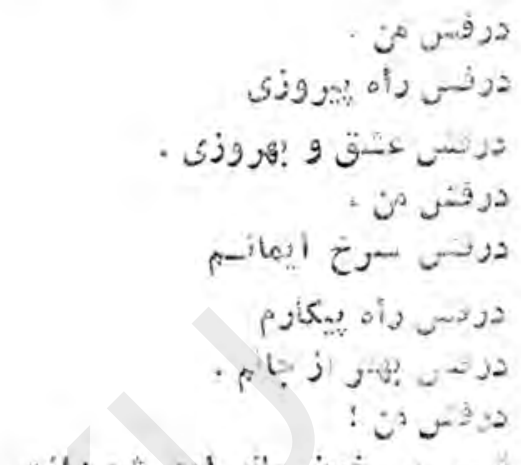

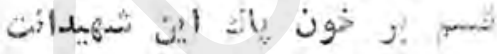

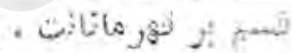

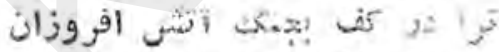

$$
\begin{aligned}
& \text { 䒠 }
\end{aligned}
$$

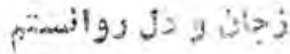

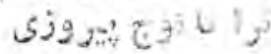

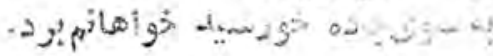

$$
\begin{aligned}
& \text {. } \\
& \text { jig } 2 \mathrm{e}^{-5} \\
& \text { مازئ } \\
& \text { 家 } \\
& \text { ان }
\end{aligned}
$$

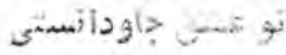

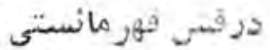

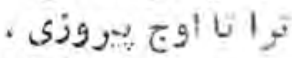

$$
\begin{aligned}
& \text {. }
\end{aligned}
$$

كابل

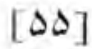




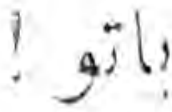

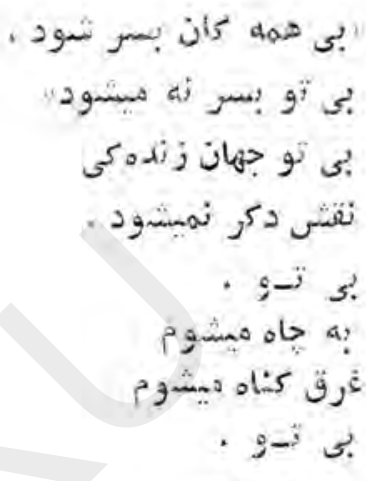
تصاه مسشنو

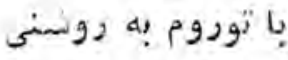

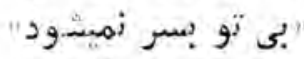
با تو روم بيه آفناب

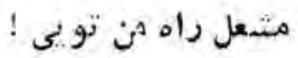

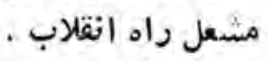
جزب إِر افتنار هن حزب زجات توده هـا -

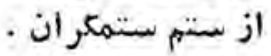

با تو روم به كهكشان .

كابل

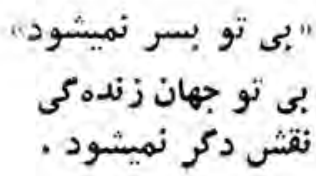




$$
\begin{aligned}
& \underbrace{}_{0} \operatorname{Ln} \dot{\theta} T \\
& \text { در بستر الهوأج نور }
\end{aligned}
$$

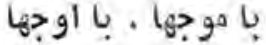

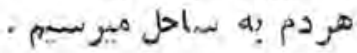

$$
\begin{aligned}
& \text { - هos } \\
& \text { در باغ كل } \\
& \text { جر باغ ميزتك هاي سرخ } \\
& \text { كى خود زعطر زند مندي. } \\
& \text { كلها به د امن همشتو يبم }
\end{aligned}
$$

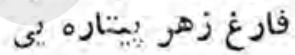

$$
\begin{aligned}
& \text { تا جاودان }
\end{aligned}
$$

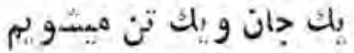

$$
\begin{aligned}
& \text { آنحا . } \\
& \text { رسيد نها خوشسيت } \\
& \text { اين دل نبيد نها خوشست } \\
& \text { آنجا همه اند } \\
& \text { در اوع صلك و دوستى } \\
& \text { در بستر امواج نور }
\end{aligned}
$$

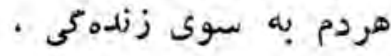

$$
\begin{aligned}
& \text { ره ميز تيم } \\
& \text { با آين همه نير نير عشق آنقلاب. } \\
& \text { تا تا آفتاب ن }
\end{aligned}
$$

كابل Ir/A

[DV] 


\section{عشق بزر كَك}

هز عسكو جانبازم · نسر بلز وتن. بازم

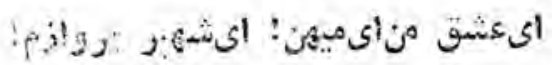

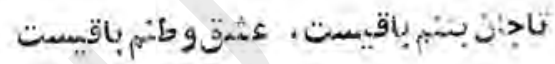

أى آتش سوزانم: أى سوزمنوسازم!

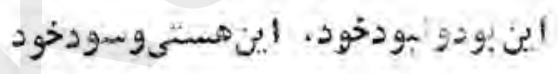

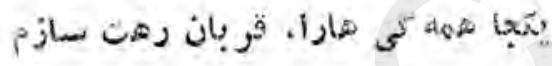

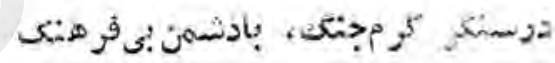

جوندستمدسنانم، جونكرد سراندازم

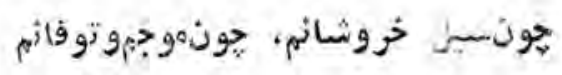

ائظمتشدورأثرا ، ازبيخ براندازم

$$
\begin{aligned}
& \text { ليلاىمنىميهز ! جونجان وتنىميهن : }
\end{aligned}
$$

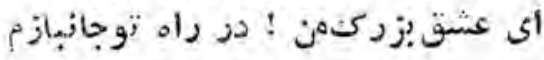

$1578 / 9 / 250$ 
به مناسبت بتجمبن سالكرد امضاى معاهده دوستى ، مملمارى و حست

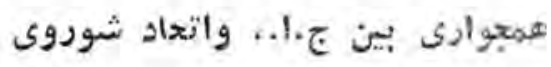

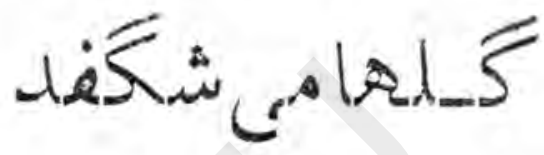

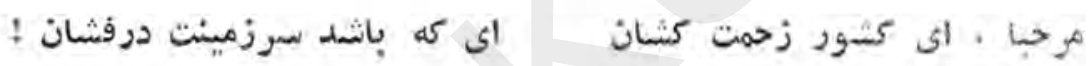

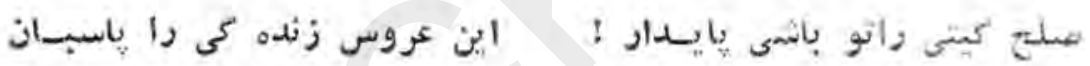

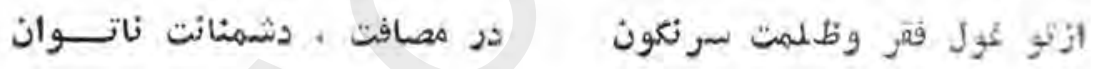

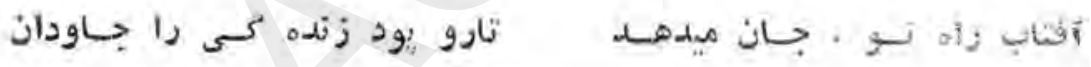

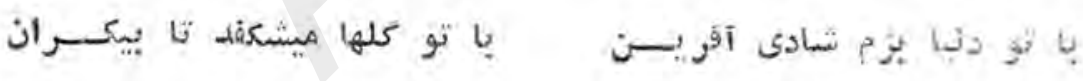

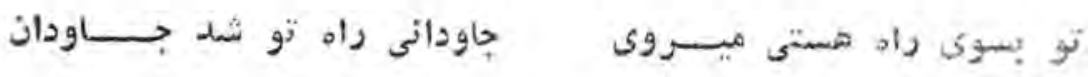

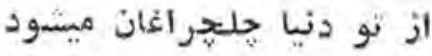

$$
\begin{aligned}
& \text { راه هستى جون بهاران هيشود. }
\end{aligned}
$$

\footnotetext{
$1678 / 9 / 1 \cdot 9$ 


$$
\begin{aligned}
& \text { in }
\end{aligned}
$$

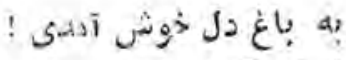

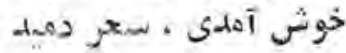

$$
\begin{aligned}
& \text { - فروغ زأله }
\end{aligned}
$$

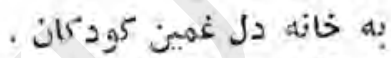

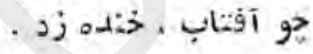

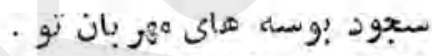

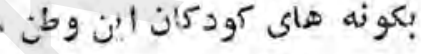

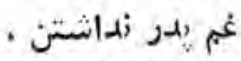

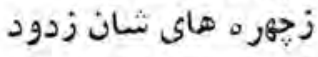

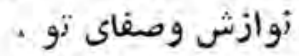

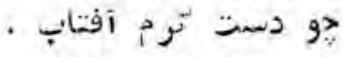

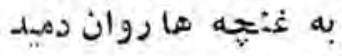

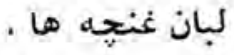

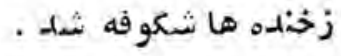

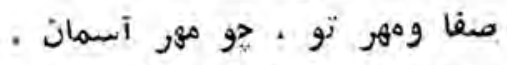

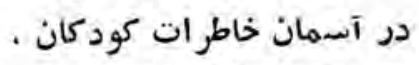

$$
\begin{aligned}
& \text { سرود جاودانه شند . شمان }
\end{aligned}
$$




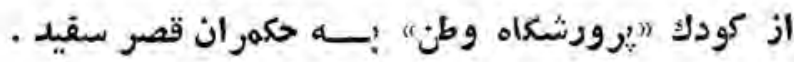

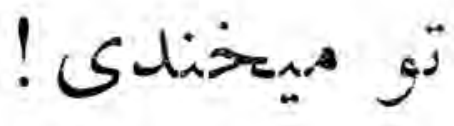

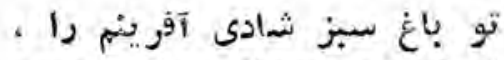

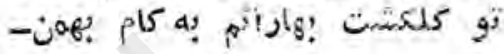

أ

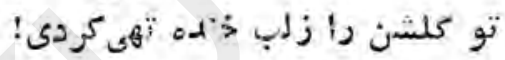

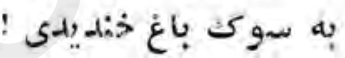

تو ميخدائى :

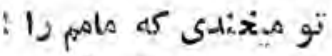

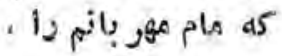

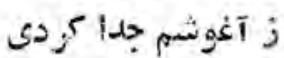

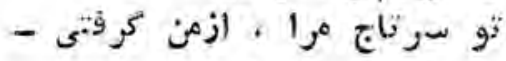

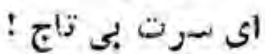

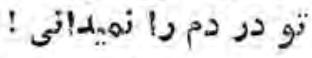

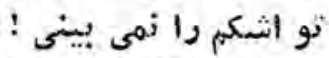

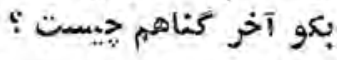

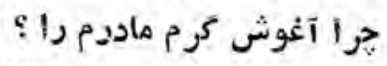

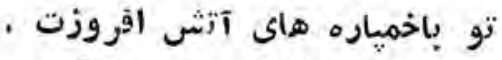

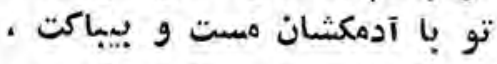

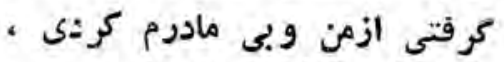

بكو آخر، تواى "ريكن" 
كه " اسللاهته همين خواهد ؟

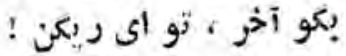

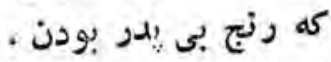

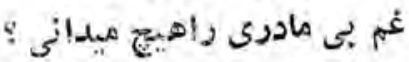

$$
\begin{aligned}
& \text { تو مينمندى : }
\end{aligned}
$$

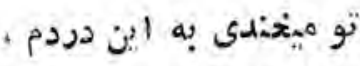

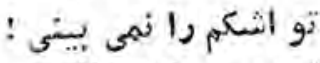

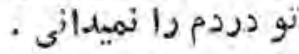

irar/ 


\section{بs:}

$$
\text { بيا تيتكلف ســر بيداد مكسر شسـو }
$$

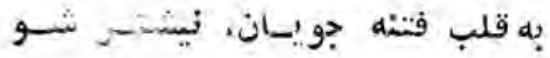

به بيكار عل و مردازــه بـر خيز

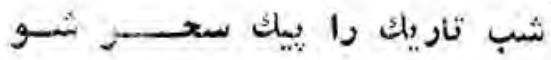

بسوزان هـــر خس و خانثـاك او را

به جان دشمنانت جـــون -ـزر ثُو

به ثور نمتان هستى كـل برويسان

جوائه زن ، جوان شو + بازور شو

اكر خوأهـى وطن كردد كلستــان

كُشاورزا : رقيــق كار كـر شم. و

تو خيلدين روز كاران رنج :-ـردى

تهاران را كنون بازيب و فـو شــو.

$$
\begin{aligned}
& \text { بيا وتك سر بيداد كر شـو } \\
& \text { به قلب فتنه جو يان نيشترشو ئر }
\end{aligned}
$$

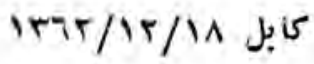




\section{قهر هـانان}

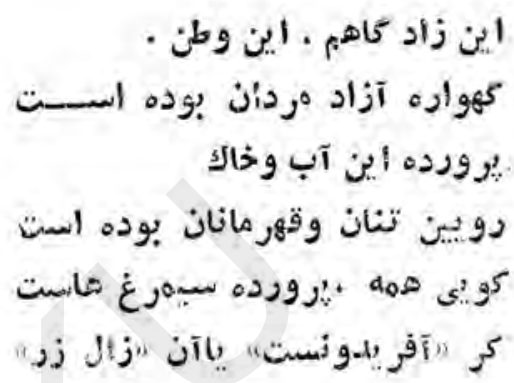

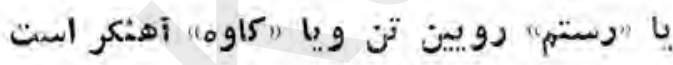

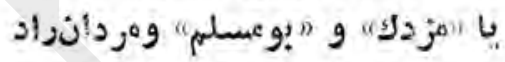

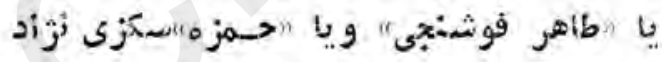

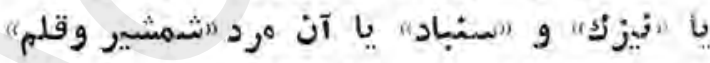

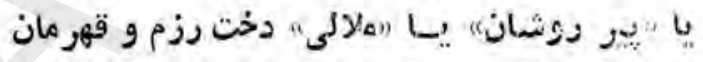

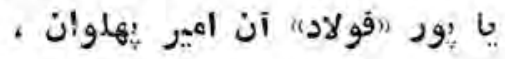

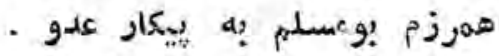

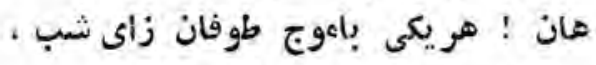

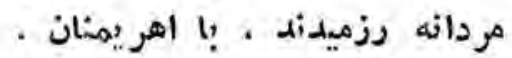

آن بور فولاد، آن "مروريهلوان"

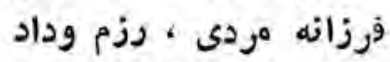

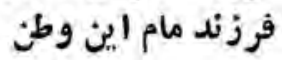




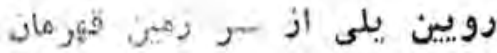

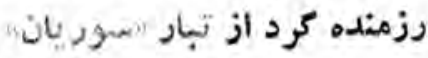

$$
\begin{aligned}
& \text { اندر نبرد دشمثنان . }
\end{aligned}
$$

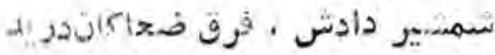

$$
\begin{aligned}
& \text { تا رايت ضملح وصفا }
\end{aligned}
$$

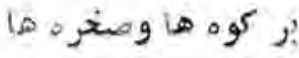

$$
\begin{aligned}
& \text { ? دئت وهامون وطن } \\
& \text { باشهد بلند - باند } \\
& \text { تا }
\end{aligned}
$$

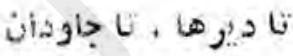

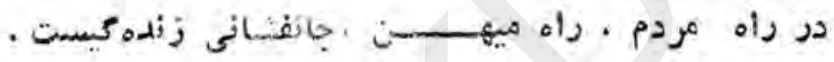

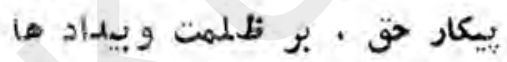

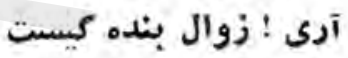

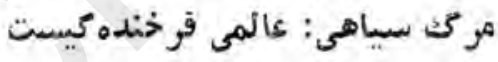
$167 / 1 / 1, j: 15$ 


\section{lis iniog golis}

$$
\begin{aligned}
& \text { ليوسه هاى كرم آفتاب ، } \\
& \text { بو بلودين شط آبى آب ، }
\end{aligned}
$$

بالحظه هاى شعفتنها ودو ويندنها

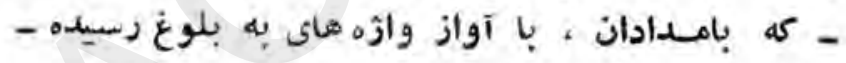

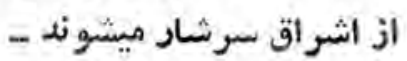
وبا بوسه هاى كرم آفناب

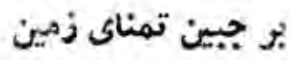

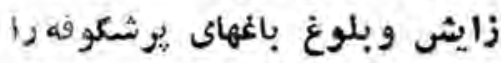

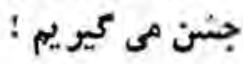

$1 \mathrm{mr} / 9 / 1 \mathrm{j}: 15$ 
تبشار آهنو يو لاد

نمى كفتر كه آغوش نبيب ات ـ

اي مقدس ما در مهين ؟ : :

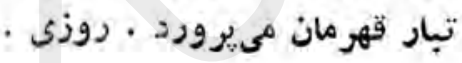

**

تبار آهن ويولاد ،

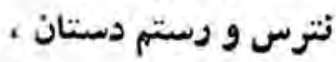

رشترف وسركث وهغرود

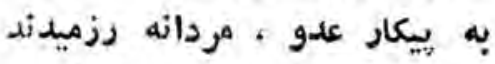

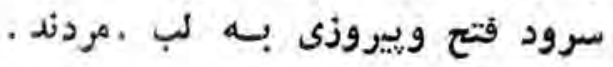
$\star \star \star$

تيام قامت ياران

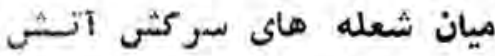
كمه رزميدند ، كان ماند

كه بان دادند

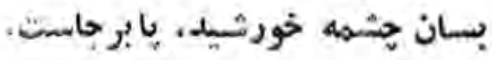

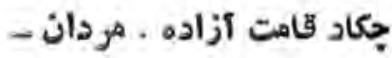




$$
\begin{aligned}
& \text { خم نمى ثرد } \\
& \text { زمسيل وتنثالدرو نوفئن }
\end{aligned}
$$

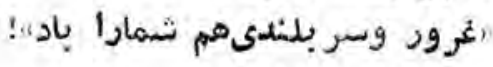

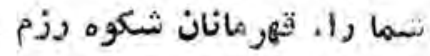

$$
\begin{aligned}
& \text { نهم كفتم ثرا مادر ؟ ! }
\end{aligned}
$$

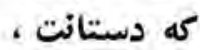

$$
\begin{aligned}
& \text { به باغستان سبز نو.ناران. لاله ميكارد . }
\end{aligned}
$$

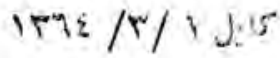




\section{posos}

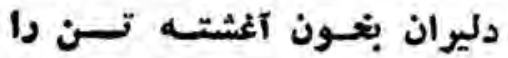

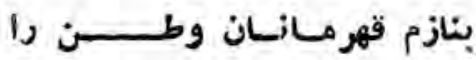

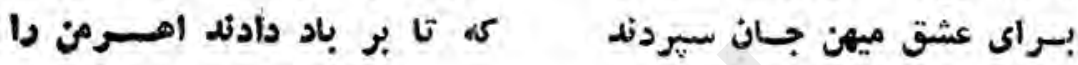

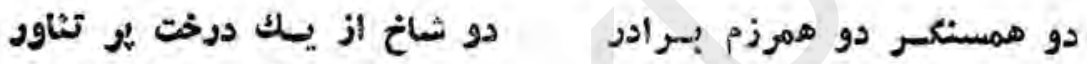

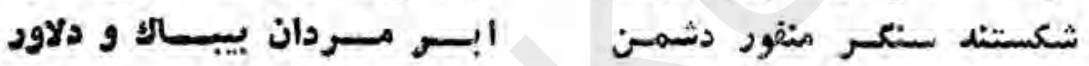

به بيكار عدو مـاران ضعـــاكي

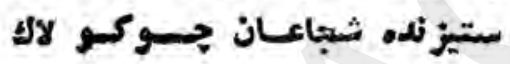

به كام شعله هـ رفتند بيباك نترس و سركش ومغرور وآزاد
سرود فتع و ييروزى سرودنســـ

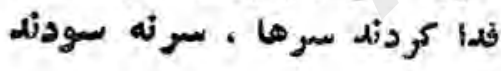

به كين دثمنان آتش كثودند سر انجام اين دو همرزم وبر ادر

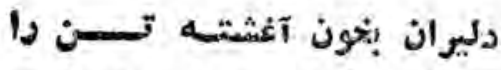

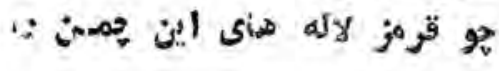

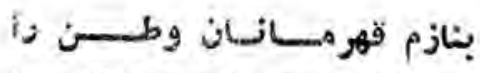

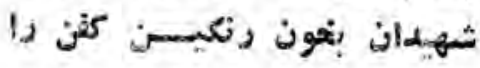

ITI /

[79] 
$d a n d a$

وطن تو عثق هن ، تو جاودان بمان

جو عمر نوريان بـر آسمان بمـن

تو اققنحار من · تو باغ زنده كسى

توبيى بهـار من مه بـ خران بمـان

به كوه ودشتها، به صنينه نبرد

تو "كاوه) : برودى . تو ثهرمان بمان

جو يج ميروى به ساحل اميــد

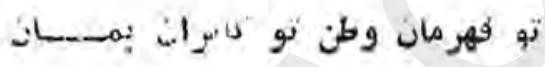

1790 jos

IV.] 


\section{$46 j ;$}

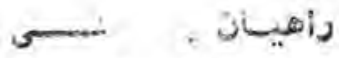

$$
\begin{aligned}
& \text { ماية فرخمانده كسى }
\end{aligned}
$$

مست كنشسق ميهندئر

هر كجأ اهر يمنست مئت

سد يون آهسن شويد

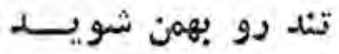

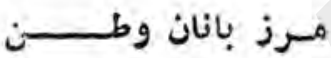

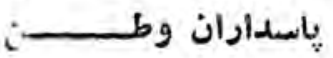

كأب $1170 / 1 / 14$

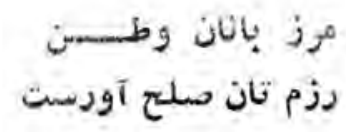

نار و يود جان بــــان ميفتد بر باى تـان

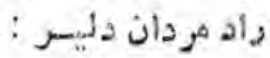

بر شكست دشمنت

$\sigma \star \star$
دزم ثان ييروز بـاد

زنده بادا نام تسـن نـان 
حصs

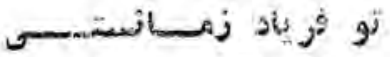

ترا

زئن و

جهان دشمئان سيس-وزد

بس است آخر بالاي جنمك

شود خامش صداى جنـ

تو جانستى ثو درمانســــم

سرودى :و زمى خواثـم

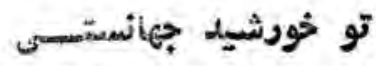

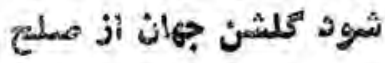

ذجفا جنأ جهان بصوزد

زصلع وآثتى بنكسر

زتو دانم، مسيح ملح :

تو ارمانم تو أيهانسم كه هرمث جز سرود صلح 


\section{دو بيتيمى}

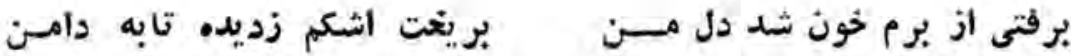

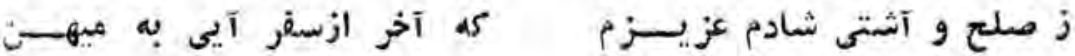

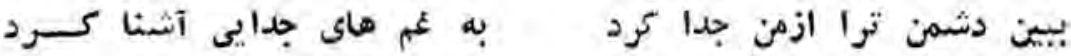

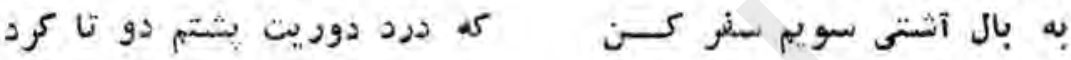

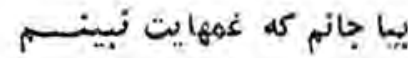
مسافر تا بكى اي نازنينيم

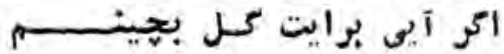

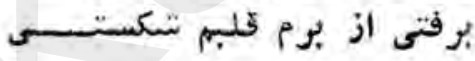

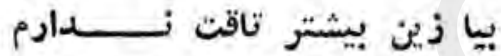

عزيزم در رمت حشم انتغلهارم

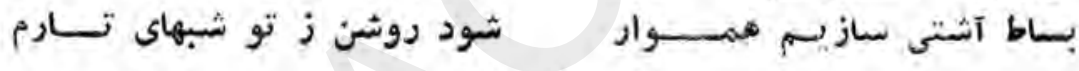

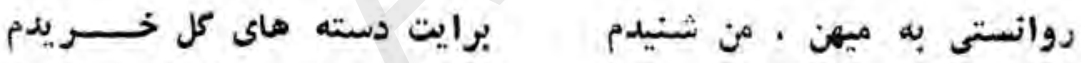

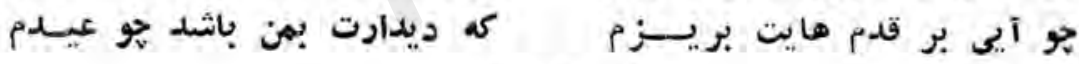

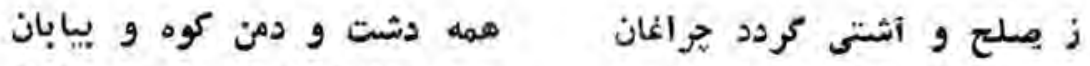

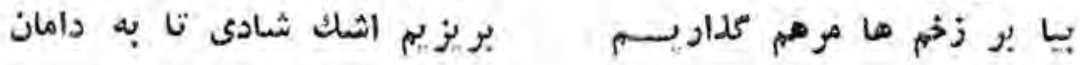

$10 / 11 / 140$

vr 
Cglb s.

$$
\begin{aligned}
& \text { إز جنون تندرو نفرين توقان }
\end{aligned}
$$

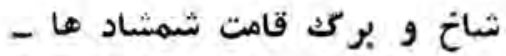

$$
\begin{aligned}
& \text { بشكست و بانمست }
\end{aligned}
$$

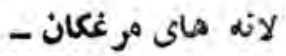

$$
\begin{aligned}
& \text { از شاخسار افتناد بر خالي } \\
& \text { بوستان ماتمسر ار شند }
\end{aligned}
$$

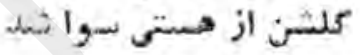

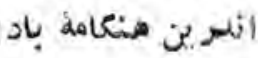

$$
\begin{aligned}
& \text { مززدع سبز بهاران } \\
& \text { 1) شعر ميلاد كويرنيستى بهان }
\end{aligned}
$$

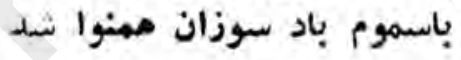

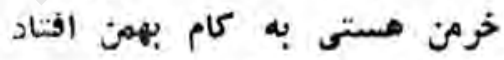

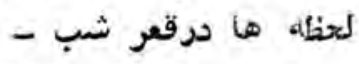

$$
\begin{aligned}
& \text { تابوت ميكاشت } \\
& \text { خار در سوكت عظيم باغ ميننديد } \\
& \text { واويلا ازين لبخند بيداد باغ مينديد } \\
& \text { با طلوع حبح خوربهم }
\end{aligned}
$$

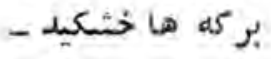

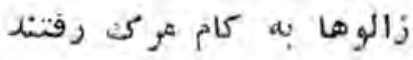

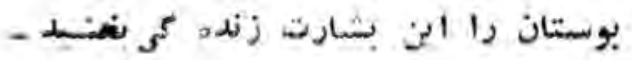


توفان رخت بربست

أسمان آيست و وند روشن

زنده كمى آمد به كلشن آيست ورثن

مزٔرع سبز بهاران

شعر ميلاد طلوع مهر هستى دار

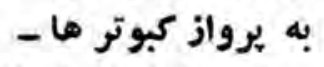

به منقار عندليبان ارمغان داد ـ مان

$17 / A / \Gamma$ J

[Yo] 


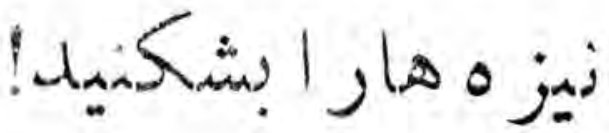

اين وطن · مميهينان جان من وجانشماست

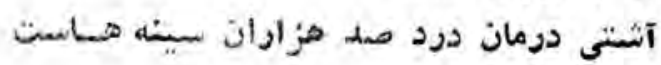

ما همه هم ميهنان ! مي خون واز يكر يشه ايم

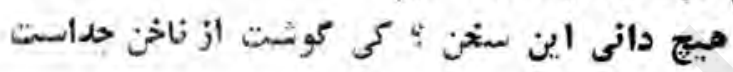

ترك ميهن بهر افغلن سنت نتكينستهان ؛

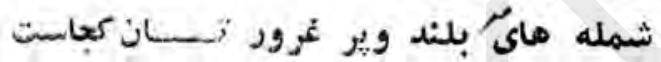

تابكى آخر به دوى يكدكر خنجسر كثيـم نيزهما را بشكنيد : كابن جنمك توفان بلاست

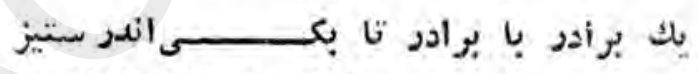

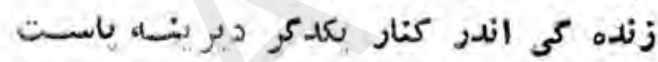

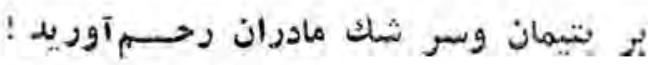

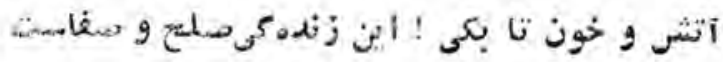

هموطن آخر بيا : يكمثت ويك بازو شُويم

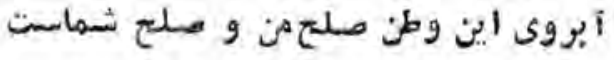

$$
1 \mathrm{rmo/1./19} \mathrm{y}
$$

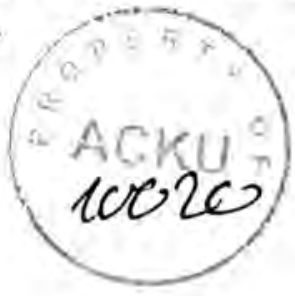



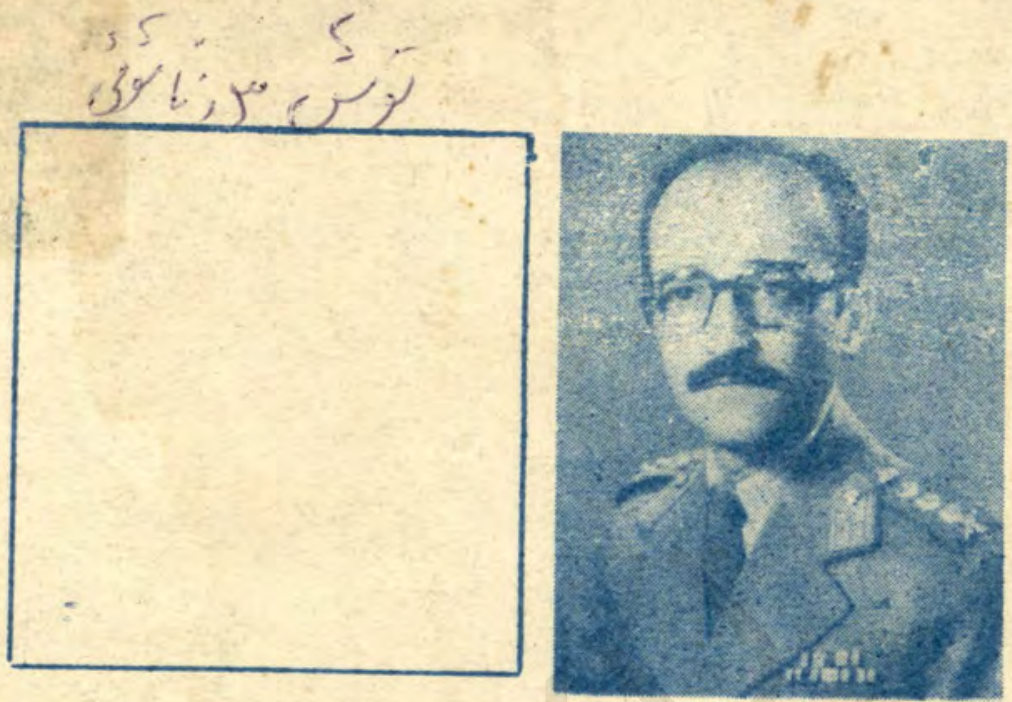

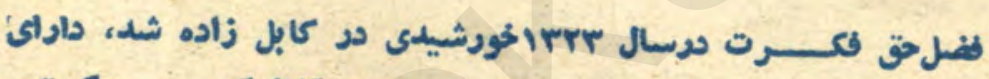

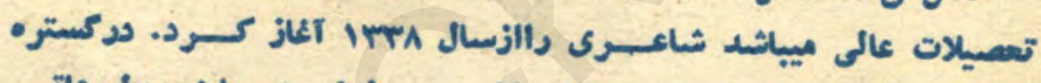

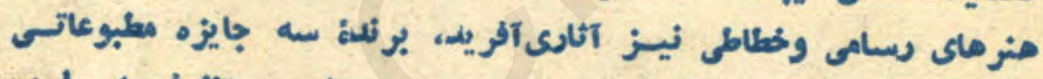

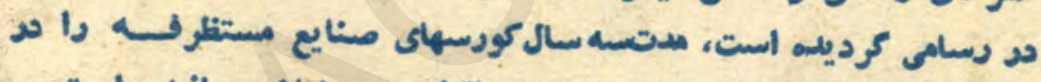

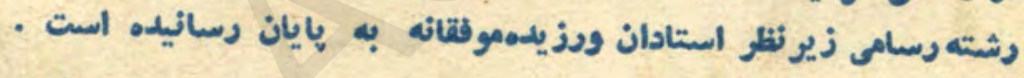

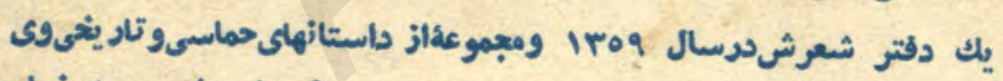

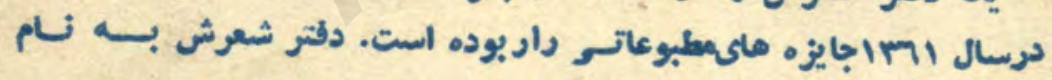

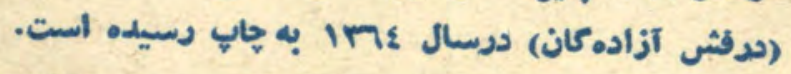

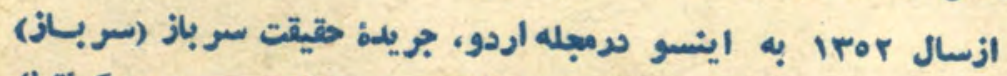

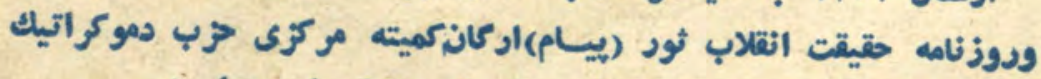

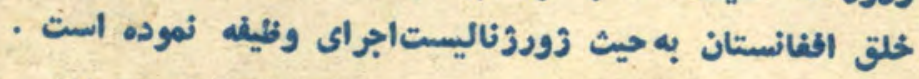
نشر كردة: نشرات نظامى دياست

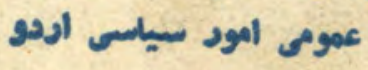

